\title{
A INDÚSTRIA TRANSFORMADORA NA REGIÃO NORTE: EFEITOS DA INTEGRAÇÃO EUROPEIA, 1986-1995*
}

\author{
José M. Amado Mendes* \\ António Rafael Amaro** \\ Manuel Ferreira Rodrigues***
}

\begin{abstract}
A integração de Portugal na Comunidade Económica
Europeia/UniãoEuropeia, a partir de 1 de Janeiro de 1986, constituiu um marco significativo da nossa História recente. Por isso, há que avaliar quais as repercussões de tal integração, sob os diversos pontos de vista. No estudo que se segue, focaremos o assunto apenas no que concerne à indústria transformadora na Região Norte. Começa-se por enquadrar, histórica e geograficamente, a área em estudo, ou seja, a dita Região Norte. Esta integra diversas subregiões, com as suas especificidades, sobretudo em termos de actividades predominantes e do respectivo desenvolvimento económico. No que à indústria diz respeito, destaca-se o Vale do Ave que, por isso mesmo, merece uma atenção especial. Seguidamente, analisam-se os recursos humanos, particularmente no que toca à qualificação escolar dos trabalhadores por conta de outrem e respectiva evolução, no periodo em foco (1986-1995).A melhoria da
\end{abstract}

\footnotetext{
* Faculdade de Letras da Universidade de Coimbra; Pólo de Viseu do Centro Regional das Beiras da Universidade Católica Portuguesa; investigador do Centro de Estudos Interdisciplinares do século XX (CEIS 2O).

** Pólo de Viseu do Centro Regional das Beiras da Universidade Católica Portuguesa; membro do Centro de Estudos Interdisciplinares do século XX (CEIS 2O).

*** Universidade de Aveiro; membro do Centro de Estudos Interdisciplinares do Século XX (CEIS XX).
} 
José M. Amado Mendes, António Rafael Amaro e Manuel Ferreira Rodrigues

qualificação dos efectivos, relativamente à sua formação, tem vindo a repercutir-se nos diversos sectores de actividade, embora de forma desigual em cada um deles. Por último, dedicar-se-á a devida atenção ao desenvolvimento industrial verificado ultimamente, com destaque para os ramos mais significativos: têxtil, vestuário e calçado. Tratando-se do principal pólo de especialização industrial português, estudam-se alguns dos elementos que caracterizam o modelo industrialização em curso, o tipo de empresas mais comum, a qualidade dos produtos, os factores de competitividade e os sinais de mudança.

Palavras-chave: Comunidade Económica Europeia/União Europeia, Região Norte, indústria transformadora, empresa, têxtil, vestuário, calçado, competitividade.

\section{INTRODUÇÃO}

Portugal, ao longo de cerca de três décadas (do início dos anos 1930 ao final da década de 1950), manteve-se relativamente fechado ao exterior. Terminado aquele período, geralmente classificado de autarcia, entrou-se num novo ciclo, caracterizado não só pela abertura ao exterior como pelas profundas transformações então verificadas. Como já foi sublinhado, «nestas três décadas e meia (1960-1995), a "modernização" da sociedade portuguesa foi profunda. Foi, sobretudo, muito rápida» (Barreto, 1996: 57).

A electrificação ia-se difundindo pelo país - inclusive no hinterland -, permitindo que a televisão, inaugurada em 1957, chegasse a um número de lares cada vez mais elevado. De 1950 a 1974, o crescimento da economia portuguesa atravessou um período já chamado "de ouro" (Mateus, 1998: 77-79). A propósito, escreveu Abel Mateus: «O período subsequente à II Guerra Mundial e até 1973 é a época de ouro do crescimento português, com uma taxa média de 5,6\% do PIB per capita, entre 1953 e 1973. Este crescimento não se deveu apenas à continuação da forte acumulação de capital físico, notando-se no decurso do período uma progressiva dominação do factor progresso técnico. A produtividade total cresceu ao ritmo médio de $3,5 \%$ ao ano» (Ibidem).

O forte surto emigratório, por um lado, e a guerra colonial em África (1961-1974), por outro, provocando escassez de mão-de-obra, induziram uma certa modernização tecnológica, nos sectores primário e secundário. 
Na sequência de um processo que já se iniciara nos anos 60 - com a integração de Portugal na Associação Europeia de Comércio Livre (EFTA), como um dos países fundadores, em 1960 - e aproveitando-se da conjuntura favorável, criada pela revolução de 25 de Abril de 1974 e consequente descolonização, Portugal solicita formalmente, em 28 de Março de 1977, a sua adesão à Comunidade Económica Europeia (CEE). Assinada a adesão em meados de 1985 (mais precisamente em 12 de Junho), a integração tornou-se efectiva em 1 de Janeiro de 1986.

A partir dessa altura, alcançada também a estabilidade política, o país entrou num novo período de desenvolvimento socioeconómico, no âmbito do qual as empresas desempenharam um papel fundamental. Protagonistas, por um lado, e espectadoras, por outro, por elas tem passado muito da história económica e social, durante a primeira década de integração de Portugal na CE/UE. Acerca do assunto, destaca João Freire: «Numa investigação por nós realizada sobre uma boa amostra da nossa indústria (120 empresas), pudemos apurar que um importante processo de mudanças, quer técnicas quer organizacionais, terá ocorrido no período inicial de 1986-1990, em ligação com o crescimento empresarial experimentado (economia, emprego, implantações). E as previsões iam então no sentido do prosseguimento das mudanças» (Freire, 1998).

Torna-se difícil, para não dizer impossível, "isolar" os factores decorrentes da referida integração dos restantes. Todavia, com base em estudos já elaborados e em fontes estatísticas disponíveis, procuraremos sublinhar algumas das repercussões da adesão, na indústria transformadora da Região Norte. As características desta - periféricas ou, se se preferir, semi-periféricas - possibilitam a realização de estudos comparados com os de outras regiões do mesmo tipo, designadamente de Espanha, do México, do Brasil e do Uruguai. No âmbito da União Europeia (UE), a Região Norte de Portugal apresenta semelhanças com outras do Reino Unido, da Alemanha, de Itália da Grécia e de Espanha (Eurostat: 3).

Acrescente-se que, provavelmente devido à já referida dificuldade em discriminar a importância relativa dos factores em presença, a literatura disponível não fornece grande ajuda, quando se pretende avaliar os efeitos da adesão. Embora se verifique unanimidade, acerca das consideráveis transformações concretizadas no período em foco, só esporádica e pontualmente se associam as ditas transformações ao processo de adesão propriamente dito. Torna-se, pois, necessário efectuar estudos sistemáticos sobre o assunto, sempre que possível a completar com a elaboração de case-studies, relativos às empresas/organizações. 


\section{ENQUADRAMENTO HISTÓRICO-GEOGRÁFICO E INDUSTRI- ALIZAÇÃO}

\subsection{Região e sub-regiões}

Apesar das reticências de alguns autores ao uso do conceito de "região" - sobretudo ao de "região natural", classificado por Yves Lacoste como conceito obstáculo (Lacoste, 1977: 41-49) -, usá-lo-emos aqui, em virtude de o mesmo se encontrar já consagrado e de não abundarem as alternativas. Só muito raramente o referido conceito tem sido substituído pelo de "área" (Mendes, 1984: 5-11), a despeito de este se tornar mais operacional para o estudo de certas realidades socioeconómicas.

Obviamente que, para os objectivos deste estudo, não interessa tanto o conceito de "região natural" como o de "região económica ou "económica e social", dada a importância que deve atribuir-se a factores como os seguintes: acessibilidades, rede de transportes e comunicações, espaço-tempo, matérias-primas, mercado, etc.

Do ponto de vista geográfico, Orlando Ribeiro agrupou as regiões portuguesas em espaços mais vastos, consoante as influências atlânticas e/ou mediterrâneas e a proximidade ou o afastamento do litoral. Definiu, assim, as seguintes divisões principais da terra portuguesa: Norte Atlântico, Norte Transmontano e Sul (Ribeiro, 1986: 144-146).

Considerando, fundamentalmente, o meio físico - como fez o autor citado - e, dentro deste, os três factores preponderantes (mar, altitude e distâncias e respectivas influências), compreende-se a inclusão do Centro e do Norte na mesma área, bem como a distinção, dentro daquela, das zonas litoral e interior.

Noutros estudos, porém, embora se incluam o Norte e o Centro numa mesma região, distinguem-se, no âmbito daquela, duas sub-regiões. Norte e Centro. Todavia, para uma análise mais detalhada, consideram-se ainda:

- Sub-região Norte: Minho-Lima, Cávado Vale do Ave, Grande Porto, Tâmega, Entre Douro e Vouga, Douro e Alto Trás-osMontes;

- Sub-região Centro: Baixo Vouga, Baixo Mondego, Pinhal Interior Norte, Dão-Lafões, Serra da estrela e Beira Interior Norte (Delgado e Godinho, 1994: 43).

A grande Região Norte, integrada pelos referidos agrupamentos de concelhos, de modo algum constitui uma realidade homogénea, 
nomeadamente no que respeita ao grau de especialização/diversificação do seu tecido industrial e à natureza e desempenho das indústrias nela implantadas. Destaca-se, desde logo, a litoralização da indústria transformadora na Região. De Facto, como sublinham Ana Delgado e J. Godinho, «as unidades territoriais que integram a faixa litoral, do Cávado ao Mondego, concentram no seu conjunto mais de $90 \%$ do valor regional do emprego, do valor acrescentado bruto ou do valor bruto da produção da indústria transformadora» (Delgado e Godinho, 1994: 129).

Importa sublinhar também que esta região constitui, com a Galiza, uma Euro-região (IGE-INE' ${ }^{1994-97: 21)}$. Por seu lado, o Atlas das Empresas Galiza-Norte de Portugal subdivide a Região Norte em oito sub-regiões, corroborando, com mais detalhe, a afirmação de Delgado e Godinho:

- Sub-região Alto-Trás-os-Montes: a maior sub-região em superfície, com 14 concelhos, detém, no entanto, apenas 6,5\% da população;

- Sub-região Douro: englobando quase toda a Região Demarcada do Douro, a agricultura e a viticultura são a principal base económica desta sub-região. Aqui vivem 7\% dos habitantes da Região Norte;

- Sub-região Tâmega: marcada por grandes disparidades e assimetrias, com uma forte concentração da actividade económica nos concelhos de Felgueiras, Amarante, Penafiel, Paredes e Paços de Ferreira, nesta sub-região reside $15 \%$ da população;

- Sub-região Ave: constitui um dos pólos mais dinâmicos de toda a Região Norte. A sua população representa 13\%, distribuída maioritariamente por três dos concelhos (Guimarães, Famalicão e Santo Tirso);

- Sub-região Cávado: ali reside $10 \%$ da população da Região Norte, dispersa pelos 6 concelhos, ainda que a maioria se concentre nos de Braga e Barcelos, onde, de resto, se concentram $84 \%$ das sociedades, $86 \%$ do emprego e $84 \%$ do volume de vendas;

- Sub-região Minho-Lima: fazendo fronteira com a Galiza, aqui reside cerca de $7 \%$ da população da Região Norte. Viana do Castelo e Ponte de Lima concentram metade da população e da actividade económica desta sub-região;

- Sub-região Grande Porto: aqui reside $34 \%$ da população e estão sedeadas $49 \%$ das sociedades da Região Norte;

- Sub-região Entre Douro e Vouga: em área representa apenas $4 \%$ da Região Norte de Portugal, mas possui uma densidade populacional de cerca do dobro da média da Região Norte. A sua actividade económica justifica $10 \%$ do volume de vendas da 
região, evidenciando-se os concelhos de São João da Madeira, Oliveira de Azeméis e Santa Maria da Feira.

Assim, enquanto alguns concelhos do interior se foram desindustrializando - por exemplo, a produção da seda e dos lanifícios, em Trás-os-Montes e na área da Serra da Estrela, respectivamente -, os de mais fácil acesso, junto ao litoral ou bem servidos por ferrovias ou rodovias, continuaram a atrair empresários, para nelas instalarem as suas indústrias.

Como foi recentemente salientado, «com $21194 \mathrm{~km}^{2}$, a Região Norte representa $23 \%$ da superfície total do Continente, enquanto a sua população (3 452263 hab.) corresponde a $35 \%$ da população total do país. A sua densidade é de $163 \mathrm{hab} . / \mathrm{km}^{2} \gg$ (QCA, 1994-99). Engloba oito regiões (NUNS III) e oitenta e quatro concelhos.

A Região Norte apresenta-se como uma das mais dinâmicas do país, não obstante a sua área, relativamente exígua. Além da elevada percentagem populacional que concentra ( $35 \%$ do país, como se disse já), como uma percentagem demográfica superior à média nacional (163 versus 112), a sua população é relativamente jovem, o seu universo empresarial é numeroso e diversificado e a sua classe empresarial é bastante activa e empreendedora (Custódio, 1994; Sousa, 1996). O que acaba de referir-se é igualmente comprovado por outros indicadores, designadamente: VAB, PIB per capita, volume de produção, número de sociedades - 50000 (31\% das quais na indústria), contra 20000 da Galiza (40,4\% das quais na indústria), apesar de a Galiza gerar 42,7\% do volume de vendas de toda a Euro-região -, etc.

Todavia, a Região Norte tem-se confrontado também com algumas restrições - em infra-estruturas, meios de comunicação e formação de recursos humanos -, as quais têm vindo a refrear o pleno aproveitamento das potencialidades acima referidas.

\subsection{Resenha histórica da Região Norte}

A Região Norte tem uma história mais que milenar, a qual precede, inclusive, a própria história de Portugal, como país independente (o que se verificou a partir de meados do século XII). Recordem-se os estudos acerca do legado pré-nacional de, entre outros autores, Martins Sarmento, Alberto Sampaio e Orlando Ribeiro. Com efeito, o nome de Portugal teve origem no Norte (provém de Portus Cale, porto da margem esquerda do 
rio Douro, junto à cidade do Porto). Guimarães foi não só o "berço" da Nação, como a sua primeira capital, sucedendo-lhe Coimbra e, posteriormente, Lisboa (esta a partir do século XIII).

Aquela Região desempenhou um papel importante na dinâmica da expansão ultramarina (séculos XV-XVI) e, nas centúrias mais recentes, continuou a ser palco de significativos eventos da história de Portugal. Recordem-se apenas alguns casos.

A conhecida sub-região do Douro - onde se produz o famoso vinho do Porto - começou a adquirir importância por meados do século XVII, tendo a partir de então registado um desenvolvimento considerável, particularmente após a celebração de conhecido tratado luso-britânico de Methuen (1703) e, de modo muito especial, a partir da demarcação da área de vinhos do Douro e da criação, pelo Marquês de Pombal, da Companhia das Vinhas do Alto Douro (1756).

Nos finais do século XVIII, verificava-se um certo desenvolvimento agrícola no Norte - com a difusão do pinheiro, da vinha e da oliveira -, ao mesmo tempo que certas indústrias, como as do linho e da seda, no Minho e em Trás-os-Montes, respectivamente, progrediam também. Não deixa de ser curioso, por exemplo, o facto de as mais recentes tecnologias então utilizadas na indústria da seda, provenientes do Piemonte, terem sido introduzidas, no país, precisamente na província de Trás-os-Montes (Mendes, 1993: 55-62).

Também a história de Portugal do século XIX está indissociavelmente ligada à Região em foco. Politicamente, basta referir as seguintes revoluções ou tentativas revolucionárias: Revolução Liberal (1820), Setembrismo (1836), Maria da Fonte e Patuleia (1846-1847) e ainda a primeira tentativa de revolução republicana (1891.01.31).

Do ponto de vista económico - e, mais especificamente industrial -, o Norte não esteve à margem do processo de industrialização que, na altura, percorria diversos países da Europa e da América (de modo especial os Estados Unidos da América do Norte). Acerca do dinamismo industrial do Porto (tradicionalmente considerado, aliás com inteira justiça, a capital do Norte), já Joel Serrão sublinhava, em 1953: «Até 1830, pelo menos (...), o Porto encontra-se à frente do esforço de industrialização portuguesa» (Serrão, 1980: 86).

Mais recentemente, chamou-se a atenção para a crescente ocupação de mão-de-obra feminina e para o aumento da produtividade, na indústria portuense, sobretudo entre 1845 e 1852 (Magalhães, 1988: 124). Nas três décadas imediatas (1851-1881), a Região Norte continuou a industrializar-se, embora lentamente e de forma desigual, nas diversas 
áreas, como revela o Inquérito Industrial de 1881 e o excelente contributo que lhe foi dado, entre outros, por Oliveira Martins.

Também foi a Região Norte que forneceu os principais contingentes à emigração portuguesa que, na segunda metade do século XIX e primeira do século XX, atingiu valores elevados. Em cerca de um século (18641960), terão emigrado do país aproximadamente quatro milhões de pessoas, isto é, o equivalente a metade da população portuguesa na última data referida.

Ao longo do século XX, a despeito de algumas vicissitudes condicionamento industrial, dos anos 30 aos inícios dos anos 70 (Brito, 1989) e certo menosprezo pelo desenvolvimento industrial e urbano, nas primeiras décadas do Estado Novo (Mendes, 1996) -, o Norte continuou a manifestar um considerável dinamismo.

Assim, a indústria passou a invadir certos meios rurais (como o Vale do Ave, entre outros) e a modernizar-se; foram-se instalando certos ramos industriais ou substituindo outros (por exemplo, o têxtil algodoeiro vai ocupando o lugar tradicionalmente reservado ao do linho); o sector terciário desenvolveu-se, enquanto as obras públicas e a construção registaram também um considerável progresso. A propósito do papel da Região em causa, são elucidativas as seguintes palavras de Ludgero Marques, presidente da Associação Empresarial de Portugal: «Mesmo que nos queiram apelidar de bairristas, argumento que muitas vezes utilizam para nos tentarem neutralizar, continuaremos a trabalhar, reivindicando, mostrando que $70 \%$ dos produtos exportados de Portugal levam bem visível a etiqueta Made in Portugal, sem referência à região de Portugal que os produz: a Região Norte» (Marques, 1989: 8).

\subsection{Desenvolvimento industrial da Região Norte: características e condicionalismos}

\subsubsection{Distribuição geográfica da indústria}

A indústria transformadora encontra-se distribuída pelas diversas subregiões da Região Norte, embora de forma algo desequilibrada. Assim, enquanto nas sub-regiões do Ave, de Entre Douro e Vouga, do Grande Porto, do Tâmega e do Cávado, o sector secundário absorve cerca de 50\% da força de trabalho, nas restantes os valores correspondentes situam-se entre os 18,9 e os 29,2\% (Delgado e Godinho, 1994: 135-166). 
Nas outras sub-regiões - Minho, Lima, Douro e Trás-os-Montes -, sobressai o sector primário com cerca de $50 \%$ da mão-de-obra activa, a restante ocupa-se, em percentagens muito aproximadas (cerca de $\downarrow$ em cada), nos sectores secundário e terciário. No que concerne ao Grande Porto, como seria de esperar, o sector primário ocupa um volume de mãode-obra modesto $(3,9 \%)$, situando-se o terciário praticamente ao nível do secundário (47,4 contra 48,7\%, respectivamente).

Acrescente-se que, na última década, se tem assistido a um certo grau de terciarização - o que é bem notório no Minho-Lima -, graças ao desenvolvimento do turismo, da restauração e da hotelaria, com destaque para a modalidade de turismo rural e/ou turismo de habitação, que ali tem alcançado um êxito considerável. Como já foi destacado, «o Comércio e Hotelaria é, em termos de número de empresas, a actividade com maior peso na região do Minho/Lima e as 1552 empresas do sector representam mais de 40\% do respectivo universo empresarial» (IAPMEI, 1993: 26).

\subsubsection{O factor escala das empresas}

Relativamente à escala das unidades da indústria transformadora, a grande maioria integra-se no âmbito das Pequenas e Médias Empresas (PME). Segundo o Banco Português de Investimento, considera-se PME «qualquer empresa cujo efectivo não ultrapasse as 500 unidades, as imobilizações líquidas sejam inferiores a 75 milhões de ECU $(203 \$ 902$, com base no câmbio de 1998.10.09) e cujo capital não seja detido por uma empresa de maiores dimensões, em mais de $1 / 3$, sendo estas três condições cumulativas. Em todo o caso, se se fixar o limite em 500 unidades, as PME agrupam mais de $95 \%$ das firmas da Comunidade. Asseguram mais de dois terços do emprego total: cerca de 60\% na indústria e mais de 75\% nos serviços» (Negócios: 1988: 14).

Como é sabido, as ditas empresas, apesar de poderem apresentar certa vulnerabilidade, oferecem também algumas potencialidades, nomeadamente: dinamismo, flexibilidade e propensão para a inovação (Negócios, 1988: 14).

No que diz respeito à Região Norte de Portugal, a despeito de nelas se localizarem algumas das nossas maiores empresas, são as PME que pontificam. Com efeito, em 1993 situavam-se ali 30070 empresas do ramo transformador, empregando 507796 pessoas, o que dá uma média de 17 efectivos por empresa (a média nacional, em 1993, era de 14 
trabalhadores por empresa). Sabe-se, hoje, que a pequena escala já não é vista como uma limitação (daí o voltar a admitir-se que small is beautiful), o que aliás tem vindo a ser confirmado por estudos recentes. Por exemplo, afirma-se num trabalho sobre Dimensão e desempenho das empresa portuguesas: «1) Não existe qualquer relação entre a dimensão e a rentabilidade das empresas industriais portuguesas; em média, as grandes empresas não são mais rentáveis nem crescem a taxas superiores à das empresas de menor dimensão; 2) contrariamente ao que seria de esperar, não se encontrou qualquer relação entre dimensão e variabilidade (intraclasses) das taxas de lucro ou de crescimento das empresas». E concluem os autores que temos vindo a citar: "A análise efectuada e os resultados obtidos permitem tirar algumas ilações, sendo a principal a de que a dimensão das empresas não deve ser encarada como uma condição para melhorar os desempenhos da generalidade das empresas portuguesas. A dimensão pode ter e terá certamente algumas vantagens, mas também pode resultar em ineficiências, nomeadamente na tomada de decisões e coordenação da informação» (Rei e Lisboa, 1993: 60).

À luz do que se acaba de transcrever, fácil se torna inferir que a predominância de PME, na Região Norte, não constitui, por si só, uma limitação. Ao contrário, a flexibilidade e a adaptação, rápida e permanente, aos gostos e às preferências dos clientes - caracterizados por uma diversificação cada vez maior, neste mundo pós-moderno -, são susceptíveis de se converter em vantagens competitivas, face às grandes empresas, mais voltadas para a produção em larga escala. A referida flexibilidade, embora se revele importante em vários ramos produtivos, adquire um significado especial naqueles que mais se relacionam com a moda, sujeita a rápidas variações, como sucede no têxtil, vestuário e calçado, cuja presença na região em estudo é bem conhecida e à qual nos voltaremos a referir.

\subsubsection{Diversificação/especialização industrial}

Acerca da diversificação/especialização, detectam-se algumas especificidades nas diversas sub-regiões. De facto, em algumas delas quase todos os subsectores se encontram representados. Por exemplo, na sub-região do Minho-Lima, quase todos os ramos se encontram representados, embora com o predomínio de alguns. 
Assim, naquela destacam-se, pela sua importância, os seguintes domínios: madeira e mobiliário, têxteis e confecções, metalomecânica e indústrias alimentares. As empresas são, regra geral - e salvo algumas excepções -, de pequena escala, no que se refere à mão-de-obra ocupada. Regista-se ali uma média de 8,2 trabalhadores por empresa, versus as médias de 17 e 14, respectivamente na Região Norte e a nível nacional.

A Região Norte ocupa um lugar destacado no âmbito dos têxteis, do vestuário e do calçado. Com efeito, em 1989 ali se localizavam 46\% das referidas indústrias (em termos de emprego), sendo o respectivo VAB (valor acrescentado bruto) de 37,3\% (Delgado e Godinho, 1994: 129).

Ora, no que se refere aos têxteis, a sub-região do Ave concentra um número considerável de unidades, do subsector algodoeiro, o que a torna demasiado dependente daquele ramo. Daquela sub-região, mais conhecida pela designação de Vale do Ave, fazem parte os seguintes seis concelhos: Fafe, Guimarães, Póvoa do Lanhoso, Santo Tirso, Vieira do Minho e Vila Nova de Famalicão. Acerca do referido Vale já foi destacado:

«Dois aspectos distintos e até certo ponto contraditórios caracterizam o panorama da indústria transformadora da região - a diversidade, no sentido de que quase todos os sectores estão representados na composição do universo empresarial transformador - e a concentração da actividade empresarial nas indústrias têxteis, uma vez que estas representam quase $65 \%$ das unidades transformadoras locais». Outros subsectores instalados «que representam maior notoriedade são a fabricação de produtos metálicos $(8,9 \%)$, as indústrias de alimentação $(5 \%)$ e as indústrias da madeira e da cortiça (4,2\%)» (IAPMEI, 1993: 24-25).

Também no Grande Porto a indústria têxtil está bem representada - ao absorver $36 \%$ do emprego e ao ser responsável por $24 \%$ do produto da indústria transformadora -, embora na dita área se localizem ainda outros pólos de especialização: vestuário e curtumes, artes gráficas, refinação e derivados do petróleo, metalúrgicas de base de metais ferrosos e não ferrosos e produtos metálicos (Delgado e Godinho, 1994: 148).

Revelando, igualmente, um determinado grau de especialização, surge-nos a sub-Região Entre Douro e Vouga, nos seguintes domínios: calçado (51,4\% do emprego e $56,2 \%$ do valor acrescentado bruto), da madeira e cortiça $(24,1 \%$ e $29,6 \%$, respectivamente), dos produtos metálicos, da borracha e das matérias plásticas. No tocante à produtividade, é de sublinhar a dos produtos metálicos, com um índice de 170 (Delgado e Godinho, 1994: 156-159). 
José M. Amado Mendes, António Rafael Amaro e Manuel Ferreira

Rodrigues

\subsubsection{Evolução da indústria transformadora na Região Norte (1990-1993)}

Sintetizamos no Quadro 2 e no Gráfico 1 (Anexos II e III) alguns dos indicadores relativos à evolução da indústria transformadora na Região Norte, nos primeiros quatro anos da década de 90. Independentemente de outras ilações a tirar dos dados apresentados - no seu conjunto e a respeito dos nove ramos indicados -, sublinhamos, desde já, os seguintes:

- o número total de empresas aumentou (de 29111 para 30 070), enquanto o pessoal ao serviço daquelas diminuiu (de 513557 para 507 796);

- a média de trabalhadores por unidade teve uma redução diminuta (de 17,6 para 16,8), tendo-se a taxa de desemprego mantido com taxas relativamente moderadas;

- a modernização - tecnológica e de gestão - deve ter-se repercutido mais na produtividade e nos níveis de produção que na economia da mão-de-obra.

Como se pode verificar pela variação do $\mathrm{VAB}$, alguns ramos industriais evoluíram mais favoravelmente: papel, artes gráficas e publicidade, indústrias químicas, metálicas e de máquinas. Mais modesto foi o comportamento das indústrias têxteis do vestuário e do couro, por um lado, e as metalúrgicas de base, por outro.

As referidas diferenças, na evolução dos subsectores mencionados, foram também confirmadas, de um modo mais geral, através de estudos empíricos, efectuados por António Brandão Moniz que, a propósito de algumas das indústrias mencionadas acentua: «Verifica-se serem sobretudo os sectores da indústria química e metalomecânica os mais permeáveis à inovação tecnológica» (Moniz, 1998: 129).

Note-se, ainda, que a já tradicional e recorrente crise da indústria têxtil, nas zonas de maior especialização - com destaque para o Vale do Ave -, se deveu igualmente à sua excessiva concentração. A propósito, já foi notado: «A indústria têxtil portuguesa de algodão está maioritariamente concentrada no distrito de Braga. Neste distrito, a Bacia do Ave traduz uma situação ímpar em Portugal e quase única na Europa com a indústria têxtil ocupando cerca de $80 \%$ do emprego industrial -, como exemplo típico de uma região de mono-indústria que baseou quase todo o seu desenvolvimento no aproveitamento da mão-de-obra local» (Reconversão do tecido industrial ..., 1993: 5). 
Resta ainda acrescentar que se verificou, por vezes (por exemplo, de 1980 a 1989), uma evolução diferente nas indústrias têxtil e do vestuário em série: enquanto aquela registou uma redução, na sua importância relativa (de $72,49 \%$ passou a corresponder a $68,68 \%$ ), a do vestuário viu a sua variação percentual aumentar significativamente, subindo de $8,04 \%$ para 11,83\%) (Ibidem).

\subsubsection{Capital humano e Cultura de Empresa, no período de pós- adesão}

Trata-se de uma área ainda insuficientemente estudada, pelo que urge elaborar estudos de caso para, seguidamente, se tornar possível elaborar trabalhos de síntese.

A nível da gestão, convirá averiguar as condições e consequências e uma certa transição de responsabilidades de muitos dos tradicionais patrões de indústria - para usar a expressão de Maria Filomena Mónica, divulgada na sua conhecida obra sobre o assunto - para os gestores profissionais: engenheiros, licenciados em gestão, economistas, etc.

Em duas décadas (1971-1991), o número de engenheiros no país mais que triplicou, passando de 15500 para 52000 (Freire, 1998: 291). A expansão do ensino superior na Região Norte - nomeadamente à volta dos pólos do Porto, Braga e Guimarães -, bem como a formação de um número mais elevado de quadros (assunto ao qual voltaremos oportunamente), para a indústria, terá tido repercussões não só na modernização e reconversão tecnológicas, mas também na própria gestão.

Será, pois, fundamental estudar de que forma os condicionalismos, geralmente atribuídos à mão invisível - mercado e respectivas leis -, facilitados, nuns casos, ou agravados, noutros, após a adesão à CEE/UE, foram sendo alterados ou contrariados pela mão visivel do gestor, usando a conhecida expressão de A. Chandler. Embora o processo já se tivesse iniciado décadas atrás, é bem possível que a referida adesão tenha contribuído, também na Região Norte do país, para a progressiva substituição do capitalismo empresarial, de tipo familiar, pelo capitalismo de gestão (Chandler, 1988: 675).

A referida transição, mesmo a ter-se verificado, não terá sido brusca nem tão-pouco se encontrará completa. Por tal motivo, muito da tradicional cultura de empresa da Região Norte - na qual as inter-relações familiares e a sociabilidade identitárias, características de certos meios 
José M. Amado Mendes, António Rafael Amaro e Manuel Ferreira

Rodrigues

rurais- ainda se mantém como factor de agregação, mesmo que os órgãos de gestão e o próprio estatuto de muitas empresas tenham mudado, inclusive para o de sociedades anónimas. A complementaridade entre trabalho fabril e rural, por um lado, e os laços de solidariedade, entre empregadores e empregados, por outro, têm como consequências, quer uma certa "docilidade" da mão-de-obra, quer um movimento operário menos reivindicativo.

Ainda no âmbito dos recursos humanos (assunto que voltará a ser focado mais adiante), sabe-se que a quantidade e a juventude da população residente têm como adversária uma qualificação relativamente baixa. Assim, procurou atenuar-se a insuficiente e/ou por vezes desadequada formação escolar através de cursos de formação, patrocinados pelo Fundo Social Europeu (FSE) e/ou pelas associações empresariais ou ainda, inclusive, pelas próprias empresas. Muito se tem dito sobre a eficácia ou ineficácia de tais cursos mas, também neste domínio, escasseiam os estudos de balanço e avaliação. A este respeito, algumas perguntas, aliás já formuladas noutro trabalho, continuam à espera de resposta:

- «quais têm sido os efeitos, em termos de mercado de trabalho e de emprego, devido à aplicação do Fundo Social Europeu?»;

- «quais os resultados das políticas de reconversão produtiva?»;

- «tem existido uma real endogeneização no tecido produtivo dos desenvolvimentos alcançados pelos programas de I \& D?» (Moniz, 1989: 136-139).

A propósito, já foi igualmente destacado por João Freire, referindo-se ao todo nacional, mas que também se aplica, obviamente, à região Norte:

«Mudanças, sim - modernização, pouca!».

«Com referência às alterações constatadas nas nossas empresas industriais e de serviços, em particular nos últimos dez anos (1988-1998), diremos que é de realçar a dimensão do investimento realizado para a melhoria dos equipamentos e processos tecnológicos de produção (e prestação de serviços), incluindo materiais, controlo, qualidade, promoção comercial, etc., com resultados visíveis sobretudo em termos de produtividade. Este processo, em grande medida beneficiário das ajudas dos financiamentos comunitários e europeus, permitiu a sobrevivência de muitas empresas face ao choque de aberturas dos mercados. Contudo, os seus resultados foram muito condicionados por constrangimentos económicos estruturais - a concorrência, cada vez mais aberta, não só em termos europeus -, bem como contraditórios, derivados 
das políticas económicas governamentais (cambial, de crédito, fiscal, etc.)» (Freire, 1998: 304).

Em suma: a adesão, se não se revelou tão negativa para Portugal, em geral, e para a Região Norte, em particular, também não foi a "varinha mágica" que alguns esperavam (ao substituírem o "Mito do Império" pelo "Mito Europeu"). Não possibilitou - como facilmente se compreende, até pelo diminuto lapso de tempo decorrido- uma modernização satisfatória no sistema de transportes e comunicações, nem uma formação, totalmente adequada, face às carências existentes, nem tão-pouco a abolição da própria mão-de-obra infantil.

Todavia, os aspectos positivos - expansão do mercado externo, livre circulação de pessoas, capitais, bens e serviços, aprofundamento das relações económicas e culturais com Espanha, modernização tecnológica e de métodos produtivos, entre outros - ultrapassam, de longe, os negativos. Além do mais, os referidos aspectos (inclusive alguns, à primeira vista negativos) ajudaram Portugal a adaptar-se, mais fácil e rapidamente, à onda de internacionalização e de globalização que tem vindo a intensificar-se.

\section{OS RECURSOS HUMANOS NA REGIÃO NORTE: EVOLUÇÃO DO NÍVEL DE QUALIFICAÇÃO ESCOLAR DOS TRABALHA- DORES POR CONTA DE OUTREM*}

É nosso objectivo principal caracterizar, dentro da estrutura do emprego na Região Norte, a forma como evoluiu o nível de qualificação escolar dos trabalhadores por conta de outrem - dentro de um arco temporal compreendido entre 1988 e 1997 -, após a adesão de Portugal (1986) à então Comunidade Económica Europeia (CEE), actual União Europeia (UE). Os limites temporais têm, apesar de tudo, justificações diferentes: o ano de 1988, dois anos após a adesão de Portugal, parecenos ser uma boa escolha parar se começar a aferir o seu impacte económico na Região Norte; já 1997 tem uma justificação mais pragmática, que se prende com a disponibilidade das séries estatísticas. Optámos, ainda, por não fazer um tratamento anual dos dados, escolhendo como datas intermédias, por mostrarem resultados regionais mais significativos, os anos de 1991 e 1993.

A sociedade portuguesa no seu conjunto, com ritmos e modos de assimilação diferenciados, tem sido marcada nos últimos anos pela 
dinâmica da integração europeia. O discurso dominante passou a encarar esta nova etapa de Portugal como um desafio de modernização, sendo para muitos a grande oportunidade de transformar o país numa sociedade aberta e competitiva. E não tardou, têm-no apontado vários autores, que tudo o que não estivesse de acordo com o modelo da integração fosse «estigmatizado como arcaico»; e, de modo simétrico, dificilmente se concebiam estratégias de modernização que não passassem e/ou dependessem do processo de integração (Silva, 1994: 148).

Este quadro de relativo consenso entre as principais elites, não há dúvidas sobre isso, tornou mais fácil a mobilização do conjunto do país para o modelo de desenvolvimento a seguir e, no geral, pode dizer-se que, nos últimos anos deste século, Portugal assistiu a ritmos de transformações socioeconómicas e de modernização sem precedentes ${ }^{1}$. Ainda assim, nem tudo são rosas neste processo. $\mathrm{O}$ aspecto mais negativo reside, sem dúvida, na amplitude da modernização social e económica, que não consegue esconder as profundas disparidades sociais e regionais de desenvolvimento.

Por outro lado, os êxitos relativos, a nível do crescimento económico, não escondem, adverte Daniel Bessa, o facto de Portugal persistir num «modelo de crescimento bastante extensivo, isto é, em que a base produtiva não se viu muito modernizada de um ponto de vista tecnológico, e em que, portanto, o aumento do Produto Interno Bruto foi conseguido sobretudo à custa da incorporação de mais força-de-trabalho» (Bessa, 1999: 136). Facto incontornável para o conjunto do país, mas, como é evidente, mais acentuado numas regiões que noutras.

A Região Norte, território que aqui mais nos interessa, ilustra na perfeição a continuidade deste modelo de desenvolvimento. Dados recentes confirmam que, apesar de nos últimos anos se terem feito alguns esforços para romper com o modelo de produção dominante, persistem ainda na Região índices elevados de utilização de mão-de-obra barata, em grande parte atribuídos a indústrias tradicionais, geradoras de fraco valor acrescentado. Para tanto concorre o facto de o Norte, em 1996, ter assegurado $41,4 \%$ do produto industrial, não ultrapassando os $26,4 \%$ do produto nacional no Sector dos Serviços (Bessa, 1999: 137). Acrescentese entretanto, para melhor esclarecimento desta questão, que esta «aparente vocação industrial manifesta-se em especial na presença de dois grandes sectores de actividade: o têxtil, vestuário e couro, e a madeira e cortiça, em que representam, respectivamente, $79,7 \%$ e $62,1 \%$ do total nacional» (Bessa, 1999: 137). Não admira, por isso, que este domínio de uma estrutura empresarial relativamente tradicional — com 
47\% das empresas industriais do país e 51\% do emprego industrial — não encontre correspondência noutros indicadores, como sejam os de deter apenas $41 \%$ dos salários industriais e $35 \%$ do volume dos negócios da indústria portuguesa (Bessa, 1999: 138).

A Região Norte regista, como característica dominante do seu tecido económico, uma excessiva representação de actividades industriais de fraco valor acrescentado - Daniel Bessa vê aqui uma das mais significativas debilidades económicas da $\operatorname{Região}^{2}-\mathrm{e}$, ao invés, uma relativa sub-representação do Sector dos Serviços. Por sua vez, esta característica estrutural da sua economia, como não podia deixar de ser, acaba por ter consequências a nível da produtividade do trabalho: vista a Região Norte como um todo - tenha-se em consideração as profundas assimetrias intra-regionais ${ }^{3}$ - , o seu PIB per capita não ultrapassava, em 1996, os $89 \%$ da média nacional, resultado económico nada animador, sobretudo tendo em conta que este resultado apresenta apenas um acréscimo de 2\%,relativamente a 1990 (Bessa, 1999: 137).

Apresentados que estão os indicadores económicos da Região Norte que mais facilmente explicam a estrutura do emprego e a evolução da qualificação escolar dos trabalhadores por conta de outrem - dado que estas são, ao mesmo tempo, causa e consequência do processo de modernização do tecido económico -, passemos então ao ponto central deste capítulo.

\subsection{Evolução da qualificação escolar dos trabalhadores no mercado de trabalho}

\subsubsection{Estrutura do emprego na Região Norte}

Estudos recentes sobre o mercado de trabalho na Região Norte confirmam que também neste caso se pode afirmar que os últimos anos não trouxeram mudanças estruturais profundas (Castro e González, 1999: 51-67). Para os autores referidos, «entre 1986 e 1996, o mercado de trabalho desta Região continuou a caracterizar-se por uma procura em que as PME desempenham um papel primordial, em que a indústria e, dentro desta, os sectores mais tradicionais e de mão-de-obra intensivos continuam a ser os principais empregadores de uma força-de-trabalho relativamente jovem, pouco qualificada e com baixas remunerações» (Castro e González, 1999: 51-67). De acordo com este quadro, se 
José M. Amado Mendes, António Rafael Amaro e Manuel Ferreira Rodrigues

tivermos em conta dados do emprego relativos aos trabalhadores por conta de outrem, é possível salientar os seguintes indicadores: em 1997, $53 \%$ dos trabalhadores estão ligados ao Sector Secundário, contra apenas $46 \%$ no Terciário. Saliente-se, contudo, que este último sector deu sinais, nos últimos anos, de algum dinamismo relativo: aumentou a procura efectiva de mão-de-obra em cerca de $9 \%$ (em 1988 representava apenas $37 \%$ e a indústria 62\%). Apesar disso, estes resultados apresentam valores bastante abaixo da média nacional (em 1997, cerca de 60\%) (Cf. Anexos, Quadro II).

Relativamente ao emprego e ao desemprego, pode dizer-se que na Região Norte existiram dois períodos bastante contrastantes:

- um mais favorável ao emprego (1988-1991), em que a percentagem de trabalhadores contratados nos diversos sectores aumentou cerca de $12 \%$;

- e outro menos positivo (1991-1997), onde se observou uma quase estagnação no emprego $(+1,5 \%)$. Com a particularidade de se poder afirmar que o quadro só não foi mais negativo em virtude do comportamento evidenciado pelo Sector Terciário, que registou um acréscimo de procura de mão-de-obra superior a $21 \%$, "almofadando" no mercado de emprego o decréscimo registado no Sector Secundário (-11\%).

Quadro 1

TAXAS DE ACTIVIDADE

Activos/População em idade activa (\%)

\begin{tabular}{lcccccc}
\hline & \multicolumn{3}{c}{ Continente } & \multicolumn{3}{c}{ Região Norte } \\
\hline Anos & $\mathbf{1 9 9 2}$ & $\mathbf{1 9 9 6}$ & $\mathbf{1 9 9 7}$ & $\mathbf{1 9 9 2}$ & $\mathbf{1 9 9 6}$ & $\mathbf{1 9 9 7}$ \\
\hline Total (HM) & 69,6 & 69,8 & 71,4 & 70,1 & 68,5 & 70,4 \\
\hline Homens & 80,4 & 78,6 & 80,1 & 79,9 & 78,2 & 78,6 \\
\hline Mulheres & 59,6 & 61,5 & 63,2 & 61,0 & 59,6 & 62,6 \\
\hline
\end{tabular}

Fonte: Castro e González, 1999: 51.

Alguns autores procuraram explicar a diminuição do emprego na Região Norte nos últimos anos, interrompendo um período anterior bastante mais favorável, com o próprio modelo de especialização seguido na Região, ou, mesmo, com opções políticas nacionais, nomeadamente devido à centralização subsequente às privatizações (Castro e González, 1999: 51-67). Sem pôr em causa os fundamentos desta interpretação, saliente-se o facto de o emprego ter aumentado no Sector Terciário, o que 
indicia um processo lento mas continuado de afirmação deste e, porventura, o início do fim de um modelo de produção extensivo no Sector Secundário (Cf. Anexos, Quadro II).

A taxa de actividade na Região Norte, em 1997, parece não se distanciar muito dos dados nacionais (respectivamente, $70,4 \%$ e $71,4 \%$ ). De salientar, no entanto, o facto de se terem invertido as posições, relativamente a 1992 (Cf. Quadro n. ${ }^{\circ}$ 1) - em 1992, no Continente a taxa de actividade não chegava aos $70 \%$, enquanto na Região Norte atingia os $70,1 \%$, quatro anos depois os dados já tinham alterado e, em 1996, a diferença já atingia o $1 \%$ favorável à média nacional. Diferença sem grande significado, é certo, mas que se acentua no caso do emprego dos homens.

\subsubsection{Evolução da qualificação dos trabalhadores por conta de outrem}

Os dados relativos à qualificação escolar dos trabalhadores, na medida em que evidenciam o capital cultural e a qualificação da mão-de-obra, bem como os ritmos de substituição de trabalhadores de baixos níveis de escolaridade, apresentam-se como importantes indicadores dos modelos de desenvolvimento económico adoptados por países e regiões. Para além disso e tendo em conta aquilo que aqui mais nos interessa, manifestam também uma interessante correspondência com o ritmo de modernização das empresas, nomeadamente do ponto de vista tecnológico e organizativo. Acontece, porém, que muitas vezes o principal obstáculo à modernização das empresas reside na falta de mão-de-obra qualificada. Ora, todos os indicadores disponíveis para a Região Norte parecem indicar uma relativa abundância de Recursos Humanos com habilitação superior, - ainda que, porventura, existam pequenos desfasamentos entre os níveis de qualificação existentes no mercado e as necessidades imediatas da procura - que de certa forma invalidam as teses dos que procuram explicar a lenta substituição de mão-de-obra menos qualificada com base na oferta disponível. A Região Norte tem uma das populações mais jovens do país e mesmo da $\mathrm{UE}^{4}$ e, no ano lectivo de 1991-1992, $29,3 \%$ dos alunos que frequentavam o ensino superior em Portugal faziam-no em instituições do Norte, nomeadamente nas cidades do Porto, Braga, Vila-Real e Guimarães. Em 1997-1998, a Região aumentava esta oferta de formação superior para $30,8 \%$, enquanto que nos mesmos anos 
José M. Amado Mendes, António Rafael Amaro e Manuel Ferreira

Rodrigues

representava $35,9 \%$ dos alunos que frequentaram escolas profissionais (Azevedo, 1999: 69-79).

Assim sendo, parece-nos evidente que qualquer explicação sobre os baixos níveis de escolaridade da força-de-trabalho a laborar na Região Norte só pode encontrar resposta na sua própria estrutura económica.

Aliás, Castro e González adiantam a este propósito: «não parece excessivo afirmar que houve uma manifesta incapacidade de gerar uma procura de trabalho capaz de absorver, oferecendo alternativas de emprego e carreira atraentes, uma parcela significativa da mão-de-obra qualificada produzida na Região pelas instituições de ensino superior (compare-se, por exemplo, o número de licenciados anualmente em licenciaturas mais voltadas para o emprego no sector produtivo com a evolução quantitativa na Região dos grupos de qualificação mais elevados)» (Castro e González, 1999: 61). Não dispomos, infelizmente, de números totais anuais de licenciados por instituições do Norte podemos, no entanto, afirmar que no ano lectivo 1997-1998 frequentavam instituições do ensino superior do Norte cerca de 103000 alunos (Silva, 1999: 76) —, mas basta uma leitura global do quadro n. ${ }^{\circ} 2$ para facilmente se admitir que o fraco nível de substituição de trabalhadores menos qualificados não encontra justificação na falta de mão-de-obra com habilitações superiores. Basta referir que, entre 1991 e 1997, o crescimento global relativo de trabalhadores com curso superior (bacharelato e licenciatura) foi apenas de $1 \%$, o que corresponde, em seis anos, a um crescimento absoluto de 11262 empregos criados.

Apesar de tudo, este crescimento global não foi igual, nem por sectores de actividade, como veremos mais adiante, nem a nível da licenciatura e do bacharelato: o crescimento do emprego deste último nível de qualificação escolar foi muito menor, sendo mesmo nulo em termos relativos (1\%, em 1988, e igual valor nove anos depois). Comportamento do mercado de trabalho bastante estranho, quando supostamente estamos em presença de um nível de habilitação mais técnico e talhado para responder a carências específicas do sector produtivo. 


\section{Quadro 2 \\ QUALIFICAÇÃO ESCOLAR DOS TRABALHADORES NA REGIÃO NORTE}

\begin{tabular}{lrrrc}
\hline \multirow{2}{*}{ NíVEIS DE ESCOLARIDADE } & $\mathbf{1 9 8 8}$ & $\mathbf{1 9 9 1}$ & $\mathbf{1 9 9 3}$ & $\mathbf{1 9 9 7}$ \\
\cline { 2 - 5 } & $\mathbf{\%}$ & $\mathbf{\%}$ & $\mathbf{\%}$ & $\mathbf{\%}$ \\
\hline$<$ Ensino Básico & 6 & 5 & 4 & 3 \\
\hline 1. $^{\circ}$ Ciclo & 59 & 52 & 49 & 43 \\
\hline $2 .^{\circ}$ Ciclo & 18 & 22 & 24 & 28 \\
\hline $3 .^{\circ}$ Ciclo & 6 & 7 & 8 & 10 \\
\hline Ensino Secundário $^{\mathrm{a}}$ & 7 & 8 & 8 & 11 \\
\hline Bacharelato $^{\mathrm{b}}$ & 1 & 1 & 1 & 1 \\
\hline Licenciatura & 1 & 2 & 2 & 3 \\
\hline Ignorada & 2 & 3 & 4 & 1 \\
\hline TOTAL & $\mathbf{1 0 0}$ & $\mathbf{1 0 0}$ & $\mathbf{1 0 0}$ & $\mathbf{1 0 0}$ \\
\hline
\end{tabular}

a . O Ensino Secundário inclui as seguintes habilitações: para além de todos os que completaram o 12..$^{\circ}$ Ano de Escolaridade, o Curso Complementar dos Liceus (antigo 7. Ano) ou $11 .^{\circ}$ Ano Unificado, Ensino Técnico Comercial, Ensino Técnico Industrial, Ensino Técnico Agrícola e outros Ensinos Secundários (Propedêutico, Artístico, Eclesiástico).

b. No Bacharelato estão incluídos os trabalhadores com o Magistério Primário, Infantil e Enfermagem.

Fonte: Departamento de Estatística do Trabalho Emprego e Formação Profissional.

De igual modo, parece-nos ser digno de registo o peso detido no Norte pelos trabalhadores com habilitação inferior ao actual Ensino Básico (9. ${ }^{\circ}$ Ano de Escolaridade), representando, em 1997, cerca de $3 / 4$ dos trabalhadores por conta de outrem (74\%). Valores relativamente elevados, sobretudo se atendermos a que, na mesma data, apenas $11 \%$ dos empregados possuem o $3 .^{\circ}$ Ciclo completo e $15 \%$ têm mais do que o Ensino Básico.

Não se pode dizer, no entanto, que o panorama da Região Norte, a nível das qualificações escolares dos trabalhadores, se encontre mais desfasado do do resto do país, do que acontece, por exemplo, com o PIB per capita (recorde-se que o Norte tinha, em 1996, um rendimento per capita de $89 \%$ da média nacional). Se não vejamos: no conjunto dos trabalhadores por conta de outrem a laborar em Portugal Continental, em 1997, 4\% eram licenciados, 68\% tinham menos do que o Ensino Básico e $21 \%$ possuíam mais do que o 9. Ano de Escolaridade, contra, respectivamente, $3 \%, 74 \%$ e $15 \%$ na Região Norte. A própria evolução destes indicadores, entre 1988 e 1997, é muito semelhante na Região Norte e no resto do país, podendo isto significar — tal como aconteceu 
José M. Amado Mendes, António Rafael Amaro e Manuel Ferreira Rodrigues

com outros indicadores económicos — que, em matéria de modernização económica, o Norte não melhorou significativamente a sua posição relativa: em 1988, Portugal detinha um peso relativo de 2,3\% trabalhadores com licenciatura, $77,6 \%$ tinham menos que o Ensino Básico Obrigatório e $14 \%$ possuíam mais que o 9. Ano de Escolaridade (Quadro 3), contra, respectivamente, 1\%, 83\% e 9\% na Região Norte.

Quadro 3

QUALIFICAÇÕES ESCOLARES DOS TRABALHADORES POR CONTA DE OUTREM EM PORTUGAL CONTINENTAL

\begin{tabular}{lcccc}
\hline Níveis de escolaridade & $\begin{array}{c}\mathbf{1 9 8 8} \\
\mathbf{\%}\end{array}$ & $\begin{array}{c}\mathbf{1 9 9 1} \\
\mathbf{\%}\end{array}$ & $\begin{array}{c}\mathbf{1 9 9 3} \\
\mathbf{\%}\end{array}$ & $\begin{array}{c}\mathbf{1 9 9 7} \\
\mathbf{\%}\end{array}$ \\
\hline$<$ Ensino Básico & 7,0 & 5,0 & 4,4 & 3 \\
\hline $1 .^{\circ}$ Ciclo & 53,9 & 47 & 45,7 & 38 \\
\hline $2 .^{\circ}$ Ciclo & 16,7 & 19 & 20,8 & 22 \\
\hline $3^{\circ}$ Ciclo & 7,9 & 9,0 & 10,6 & 15 \\
\hline Ensino Secundário $^{\mathrm{a}}$ & 10,2 & 11 & 12,6 & 15 \\
\hline Bacharelato $^{\mathrm{b}}$ & 1,3 & 1,0 & 1,6 & 2 \\
\hline Licenciatura & 2,3 & 3,0 & 3,1 & 4 \\
\hline Ignorados & 0,7 & 5,0 & 1,2 & 1 \\
\hline Total & $\mathbf{1 0 0}$ & $\mathbf{1 0 0}$ & $\mathbf{1 0 0}$ & $\mathbf{1 0 0}$ \\
\hline
\end{tabular}

${ }^{\mathrm{a}} \mathrm{e}{ }^{\mathrm{b}}$ Cf. Quadro n. ${ }^{\mathrm{o}} 2$

Fontes: Para os anos de 1988 e 1993, Departamento de Estatística do Ministério de Emprego e Segurança Social (DE/MESS), Quadros de Pessoal. Para 1991 e 1997, Departamento de Estatística do Trabalho Emprego e Formação Profissional (DE/TEFP).

Mas, se este equilíbrio relativo na forma como evoluiu a substituição de trabalhadores menos habilitados, entre a Região Norte e o todo nacional, não sofreu qualquer alteração significativa, o mesmo não aconteceu em relação aos nossos parceiros da «Coesão»: em Portugal, nos últimos quatro anos, a percentagem de trabalhadores com estudos superiores teve um aumento relativo inferior a $1 \%$, evolução inferior à da Grécia $(2,9 \%)$, à da Espanha $(6,1 \%)$ e, sobretudo, à da Irlanda $(6,8 \%)$. Comparação negativa que também se repete na diminuição do peso relativo dos empregados que apenas dispõem de qualificações ao nível do Ensino Básico: em Portugal, a diminuição entre 1992-1996 não foi além de $-2 \%$, enquanto que na Grécia foi de $-7 \%$, na Irlanda $-8,5 \%$ e na Espanha $-8,5 \%$.

Recorrendo agora a uma malha mais apertada destes mesmos dados por sector de actividade, pode dizer-se que, em 1997, o nível de 
escolaridade mais representativo nos trabalhadores da Região Norte era, a grande distância, o $1 .{ }^{\circ}$ Ciclo (antiga $4 .^{\circ}$ classe): $59 \%$ no Sector Primário, $47 \%$ no Sector Secundário e 37\% no Sector Terciário. E, se tivermos em conta a sua evolução relativa, entre 1988 e 1997, é também possível verificar que foi neste último sector que se registou a maior percentagem de substituição de trabalhadores do $1 .{ }^{\circ}$ Ciclo, isto é, $-6 \%$, contra $-15 \%$ no Secundário e apenas $-2 \%$ no Primário. Ainda assim, não deixam de ser curiosos os dados representados nos gráficos 1 e 2: se tivermos em conta apenas a evolução dos trabalhadores por conta de outrem com 9 anos ou menos de escolaridade, verifica-se que é precisamente o Sector Terciário que mais tem absorvido mão-de-obra deste nível de formação, muito embora à custa do $2 .^{\circ}$ e $3 .^{\circ}$ Ciclos de Escolaridade. Em 1991, do total dos trabalhadores por conta de outrem ligados ao Sector Terciário, $17 \% \mathrm{e}$ $11 \%$ tinham, respectivamente, o $2 .^{\circ}$ e $3 .^{\circ}$ Ciclos de Escolaridade. Em 1997, estes mesmos níveis de habilitação detinham um peso, respectivamente, de $23 \%$ e $15 \%$. Uma subida, portanto, destes níveis de ensino que ajudam a explicar que o peso relativo do conjunto de trabalhadores daquele sector, com o $9 .^{\circ}$ Ano ou menos, tenha aumentado em 1\%, comparativamente a 1993.

\section{Gráfico 1}

TRABALHADORES COM 9 E MENOS ANOS DE ESCOLARIDADE POR SECTOR DE ACTIVIDADE

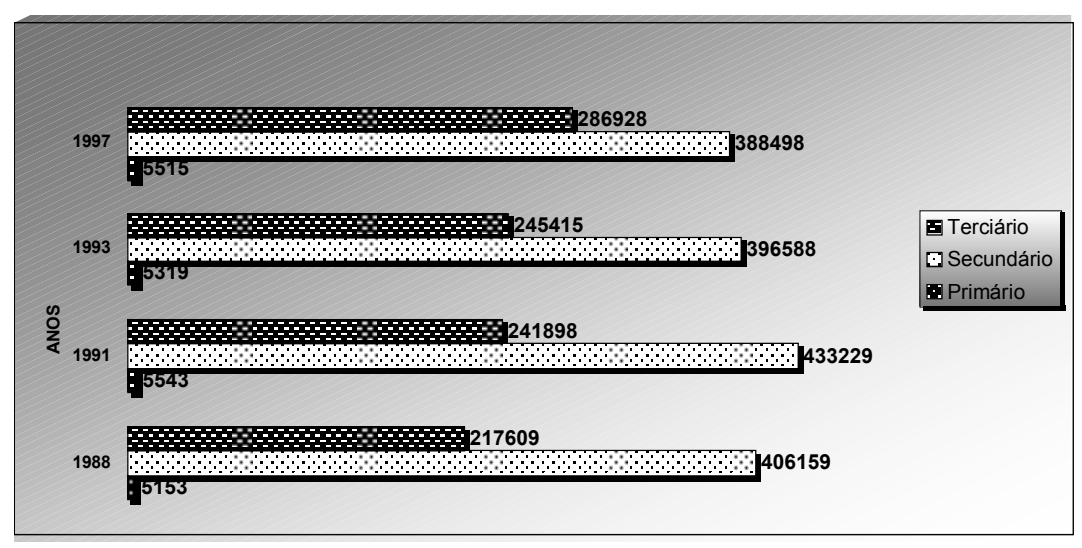




\section{Gráfico2 \\ TAXA DE CRESCIMENTO DOS TRABALHADORES COM 9 E MENOS ANOS DE ESCOLARIDADE POR SECTOR DE ACTIVIDADE}

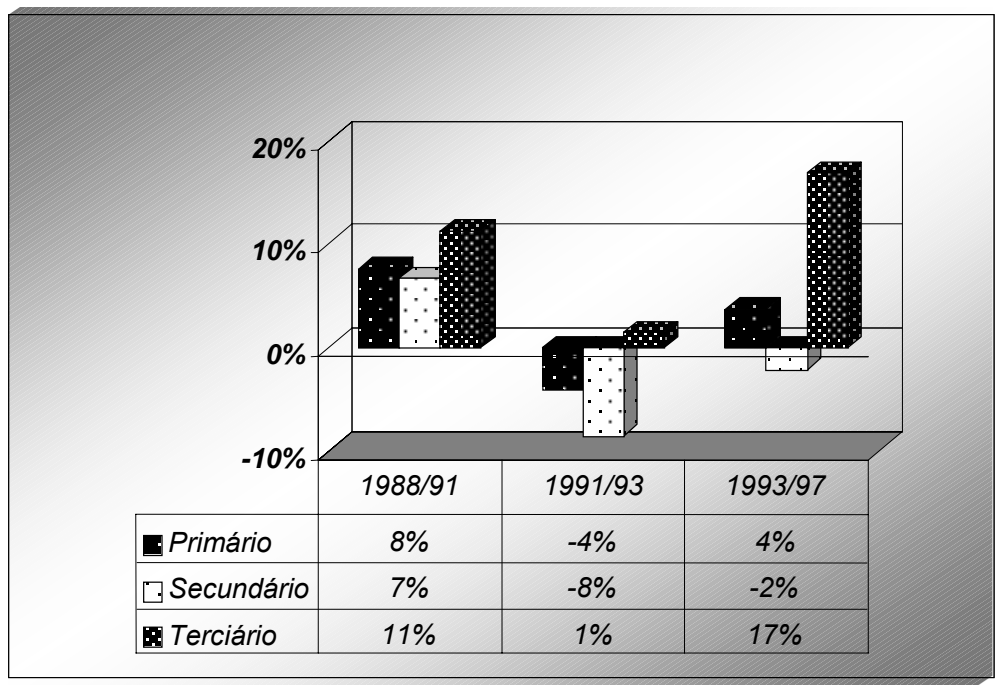

Aliás, registe-se que foi também no Sector Terciário que se deu a maior subida relativa de mão-de-obra com o Ensino Secundário ou mais: $14 \%$, em 1988, 18\%, em 1991 e 1993 e $22 \%$, em 1997. Aumento de $8 \%$ do peso relativo destes níveis de habilitação, mas sem que o Ensino Secundário perdesse importância para os níveis de habilitação superiores (Bacharelato e Licenciatura): em 1988, 11\% dos trabalhadores do Terciário tinham apenas o Ensino Secundário, contra $1 \%$ com o Bacharelato e $2 \%$ com Licenciatura; em 1997, as percentagens subiam, respectivamente, para $16 \%, 2 \%$ e $4 \%$.

Como se esperava, foi no Sector Terciário que se verificaram, entre 1988 e 1997, as maiores descidas no peso relativo de trabalhadores com baixos níveis de habilitação. Tanto o Sector Secundário como o Sector Primário tiveram, nestes nove anos, mudanças que poderemos considerar insignificativas. Se não, atente-se neste números: em 1988, o Sector Primário e o Sector Secundário tinham um peso relativo de trabalhadores com apenas o Ensino Básico, respectivamente, de 90\% e 91\%; em 1997, os mesmos sectores económicos e, pela mesma ordem, detinham $88 \%$ e 
90\%. Se agora verificarmos como evoluiu o peso dos níveis de habilitação médio e superior (Secundário, Bacharelato e Licenciatura), é possível ver que o quadro não se alterou substancialmente: o Sector Primário vê aumentar o peso relativo dos trabalhadores com este nível de habilitação em cerca de 4\% (1988 4\% e 1997 8\%), enquanto que Sector Secundário passa nas mesmas datas de $5 \%$ para $8 \%$, aumentando o peso relativo daquelas habilitações escolares em apenas $3 \%$.

Estes números dizem bem do fraco ritmo de substituição de trabalhadores de baixo nível de qualificação escolar na Região Norte, sobretudo se tivermos em consideração que, em 1997, num sector tão importante com a indústria, $47 \%$ dos trabalhadores têm apenas o $1 .^{\circ}$ Ciclo, e apenas $1 \%$ deles tem habilitação a nível da licenciatura. Se outros indicadores não existissem, bastar-nos-iam estes para aqui deixarmos algumas ideias que sintetizaríamos do seguinte modo:

- Não há dúvidas que a Região Norte — não obstante o aumento da qualidade da oferta (registe-se a criação de instituições de Ensino Superior e o esforço desenvolvido nos vários programas de Formação Profissional) - evidenciou uma manifesta incapacidade de gerar uma procura de trabalho capaz de absorver a mão-deobra qualificada produzida no Norte, adiando, por via disso, a modernização do seu tecido económico.

- Um pouco como no resto do país, o Norte adoptou um modelo de desenvolvimento bastante extensivo, em que o aumento do PIB foi conseguido à custa de mais força-de-trabalho, o que explica a fraca diminuição do peso relativo dos trabalhadores com qualificações escolares mais baixas.

- No que respeita ao ritmo de substituição de trabalhadores com níveis de qualificação inferiores, pode dizer-se que o comportamento dos principais sectores de actividade não foi uniforme: o Sector Terciário demonstrou maior sentido modernizador, sem que, no entanto, tenha atingido resultados superiores à média nacional.

- Pode dizer-se, por isso, que o baixo nível de qualificação escolar, entre os trabalhadores por conta de outrem - inferior à média nacional -, está afinal de acordo com outros indicadores económicos que evidenciam uma escassa modernização do tecido produtivo.

- Por último, tal como PIB per capita, que cresceu sem registar qualquer vantagem sobre a média nacional, também a nível da qualificação escolar houve evolução positiva, mas sem que esta 
José M. Amado Mendes, António Rafael Amaro e Manuel Ferreira Rodrigues

alterasse a comparação negativa com a média do país, já existente antes da adesão de Portugal à então CEE.

\section{O SECTOR DO TÊXTIL, VESTUÁRIO E CALÇADO, 1986-1995}

\subsection{A importância económica e industrial da Região Norte}

A Região Norte, que ocupa $23 \%$ do território nacional, detinha, no início da década de $90,35 \%$ da população, $39 \%$ do emprego, $52 \%$ do emprego industrial e dois terços das exportações nacionais. Destes dois terços, um pouco menos de metade estava ligada aos têxteis. Tinha ainda $42 \%$ do emprego agrícola e $31 \%$ dos serviços. «Se adoptássemos o critério de demarcação da Área Urbana de Lisboa, a Área do Porto ia de Viana do Castelo até Aveiro, porque há um contínuo urbano naquela zona; Lisboa é mais concentrada e muito mais populosa. A Área do Porto tem 1,2 milhões de habitantes, tem depois a coroa industrial com cerca de 1,3 milhões, distribuindo-se um milhão pela restante área. Nessa área envolvente há uma zona muito mono-sectorializada em volta do Vale do Ave e, nas restantes, a actividade económica é razoavelmente diversificada, ainda que com especializações, casos de São João da Madeira e do Vale do Sousa, em calçado e mobiliário, respectivamente» (Beires, 1994: 20-21). Depois, há todo o mundo rural na Região Norte, que nos últimos 30 anos perdeu $30 \%$ da população, e que possui pouco menos de um milhão de habitantes. Trata-se, de resto, de um fenómeno à escala nacional: os distritos do interior de todo o país retêm agora apenas cerca de $15 \%$ da população. Os números supra testemunham, afinal, a evolução espacial de Portugal, entre 1970 e 1996: ininterrupta concentração da população no litoral, crescimento urbano e suburbano à custa do despovoamento do interior do país (Machado e Costa, 1998: 18).

Como se pode ver no Mapa da Região Norte, $75 \%$ do volume de vendas de todo o Norte de Portugal concentra-se numa área diminuta, constituída por oito concelhos localizados no litoral, a Norte e a Sul da cidade do Porto. Esses concelhos concentram igualmente cerca de $75 \%$ do volume de vendas das actividades industriais, extractivas e transformadoras da Região (IGE-INE, 1994-97: 199-234). Mesmo em concelhos com grande importância económica, como Braga ou Guimarães, a actividade industrial concentra-se num diminuto número de freguesias. No conjunto em destaque, é evidente a centralidade dos 
concelhos do Grande Porto, em vários domínios, com relevo para produção de energia, transportes e comunicações, mesmo no quadro da Euro-Região Galiza-Norte de Portugal.

Depois do Grande Porto, a sub-região mais dinâmica é o Vale do Ave. Apesar da diversidade interna desta mancha - o Vale do Ave corresponde actualmente a uma associação de oito municípios, atravessados pelo rio que lhe dá o nome, com um modelo territorial caracterizado fundamentalmente pela dispersão da habitação e do emprego, localizando-se estes ao longo das vias de comunicação e dos cursos de água, com concentrações nas sedes de concelho e noutros pólos urbanos de recente crescimento ${ }^{6}-$, alguns autores preferem enfatizar a unidade e o carácter determinante da actividade industrial, especialmente na subregião do Ave. No Vale do Ave, segundo Mário Rui Silva, «os concelhos de Vila Nova de Famalicão, Santo Tirso, Guimarães e Fafe constituem uma mancha contínua de território com uma configuração relativamente bem definida quanto às condições socioeconómicas que envolvem o desenvolvimento (...). Deparamos, no Vale do Ave, com uma forte concentração de actividades industriais - de vocação sectorial dominante - que constituem o essencial da actividade económica e que, de há muito para cá, são o principal vector do desenvolvimento económico e social bem como das transformações socioeconómicas do território em causa. Dito de outro modo, a indústria é, no Vale de Ave, o essencial do sistema produtivo local» (Silva, 1987: 2).

\subsection{Os têxteis, vestuário e calçado: principal pólo de especialização industrial português}

Para uma avaliação dos impactes da integração europeia na indústria portuguesa do Norte de Portugal seleccionámos três sectores, tidos habitualmente como tradicionais: Têxteis, Vestuário e Calçado. As razões dessa escolha decorrem da importância que os referidos sectores detêm na indústria nacional e do facto de a maioria das empresas estar sedeada na região em apreço.

Constituídas na sua maior parte por pequenas e médias empresas, as indústrias Têxtil e de Vestuário portuguesas (fios, tecidos e produtos acabados) situam-se maioritariamente nos concelhos a Norte do Porto, especialmente no Vale do Ave. Isto é, estão ali sedeadas $68 \%$ das cerca de 5800 empresas existentes actualmente (Duarte, 2000: 46). A 
localização da indústria de Calçado é um pouco mais dispersa, concentrando-se nos concelhos de Felgueiras, Barcelos, Guimarães, Lousada, Maia, Vila Nova de Gaia, Santa Maria da Feira, Oliveira de Azeméis e São João da Madeira, com especial destaque para o primeiro e último dos referidos concelhos.

Por outro lado, esses sectores integram, segundo Isabel Salavisa Lança, o núcleo duro da competitividade industrial portuguesa, constituindo mesmo «o principal pólo de especialização da indústria portuguesa», entre 1970 e 1996 (Lança, 2000: 27). Portugal é o sétimo produtor comunitário de têxtil e vestuário (Duarte, 2000: 46). No início da década de 90, o Relatório popularizado com o nome de Michael Porter era eloquente: «das 100 indústrias portuguesas com maior exportação em termos de quota de exportação mundial, 46 são de têxteis ou vestuário, e a maior parte das restantes são de produtos florestais pouco ou nada transformados, minérios, pasta de papel e couro» (Monitor Company, 1994: 37). Em 1991, Portugal ocupou a 10. ${ }^{a}$ posição na lista dos maiores exportadores de vestuário, a nível mundial, com 3\% do comércio total e uma taxa média de crescimento de 17\%, nos anos 80» (Machado, 1998: 47). Ainda segundo I. Salavisa Lança, esse pólo «responde, em 1996, por $31 \%$ das exportações, 32\% do emprego e 21\% do VAB» (Lança, 2000: 27), sendo a maior fatia da responsabilidade dos Têxteis e Vestuário, que responde por $\ll 25 \%$ do emprego industrial e $28 \%$ das exportações industriais nacionais» (Sá et al., 1998: 21). 


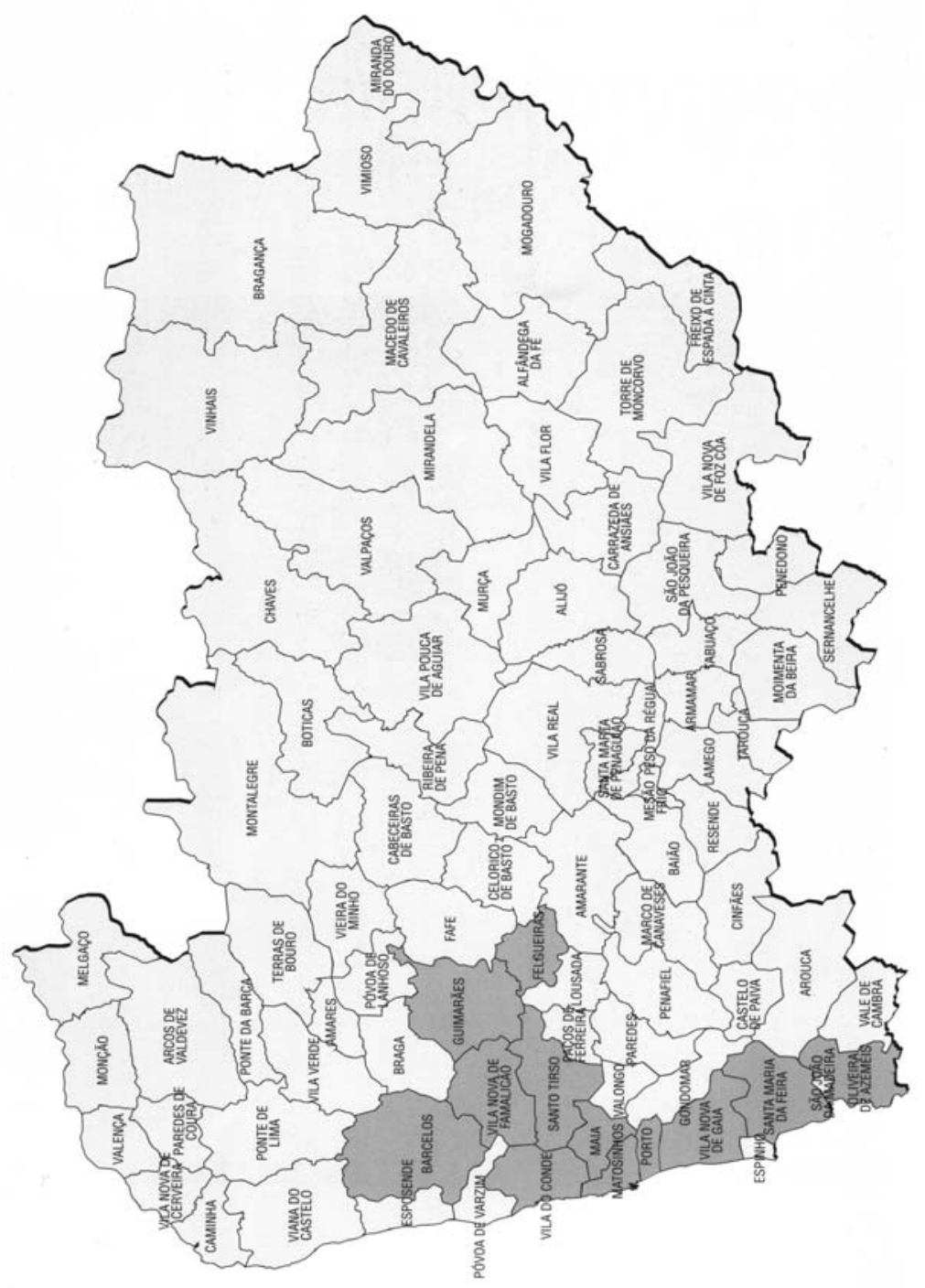


José M. Amado Mendes, António Rafael Amaro e Manuel Ferreira Rodrigues

O números disponíveis sobre o volume da mão-de-obra são igualmente expressivos, se confrontados com os da UE: os 230000 postos de trabalho (mais de 20000 "não declarados") dos Têxteis e Vestuário, em Portugal, representam cerca de um terço a mão-de-obra europeia nesses mesmos sectores (650 000) (Machado, 1998: 50), apesar da redução a que se tem assistido, nos últimos anos.

Esses três sectores exportavam, em 1996, mais de 50\% da sua produção, com tendência para aumentar ${ }^{7}$. Todos estes sectores detêm importantes quotas de exportação, em 1996, com destaque para o calçado, que passa de $1 \%$ das exportações para a OCDE, em 1970, para $11 \%$, em 1996 (Lança, 2000: 27). Nos anos seguintes, segundo Jorge Vasconcelos e Sá, os têxteis e as exportações de confecções já se cifram em 67,6\% da produção (Sá et al., 1998: 69). De facto, como referem diversos autores, especialmente na primeira metade da década de 90, «houve um incremento nítido das empresas que exportaram para a União Europeia»e o sector «onde mais pesam as empresas intensamente exportadoras é o das indústrias têxteis, do vestuário e do couro» (Lança, 2000: 67-69), tornando-as dependentes daquele mercado, o que leva I. Salavisa Lança a concluir que, «após a adesão, a Comunidade passou a ser o mercado natural da maioria das empresas industriais» (Lança, 2000: 69 e Godinho, 2000: 57).

Sublinhe-se, porém, que a interdependência económica entre Portugal e a Europa tem início com a adesão de Portugal à EFTA, em $1960^{8}$, incrementada com os primeiros acordos comerciais com a CEE, em 1972, muito antes, pois, da adesão à Comunidade Europeia, em 1986. Em 1970, Portugal importa 1162 milhões de ECU; em 1984, o valor das importações da CEE cifra-se em 14 648. No tocante às exportações, o fenómeno é idêntico: de 1802 milhões de ECU, em 1970, passa-se para 12 850, naquele último ano (Drew, 1986: 14). Quer pelas medidas impostas pela CEE, quer pela inevitabilidade das mesmas medidas sem a adesão, nos anos que antecederam 1986, assistiu-se a uma conversão estrutural - sem que isso significasse uma profunda modernização -, sentida como uma crise, especialmente nos têxteis e vestuário, cujo aspecto mais visível foi o volume de falências e a considerável redução da mão-de-obra decorrente do apetrechamento técnico e automatização dos processos de produção, especialmente nas empresas mais competitivas (Ashoff et al., 1980: XI-XIV).

Se em 1970, as indústrias têxteis, vestuário e couro constituíam já o pólo de especialização internacional mais forte, com um indicador de vantagem comparativa revelada (IVCR) de 3,52, depois dos Produtos de 
Madeira e Mobiliário (IVCR de 5,2), em 1996, a situação é completamente diferente: «primeiro porque existe agora um pólo de especialização a uma enorme distância dos outros, o têxtil-couro, com um valor do IVCR de 5,65 . Segundo, porque a ordenação foi bastante alterada. Os outros pólos de especialização, por ordem decrescente, são agora: a Madeira e Mobiliário (IVCR de 2,52 contra 5,2); os Minerais não-Metálicos (2,42 contra 1,75) e a Pasta de Papel e Artes Gráficas (1,38 contra 1,43)» (Lança, 2000: 23). Essa evolução permite afirmar que «o país é, agora, e claramente, um país de vocação têxtil que, em menor grau, se apoia também nos seus recursos naturais (madeira e minerais não metálicos)» (Lança, 2000: 23).

Ainda segundo I. Salvisa Lança, entre 1970 e 1996, «a indústria transformadora portuguesa viu a sua quota nas exportações da OCDE aumentar de $0,5 \%$ para $0,8 \%$ [...]. As indústrias responsáveis pelo aumento foram sobretudo as dos Têxteis, Vestuário e Couro, cuja quota aumentou espectacularmente de $1,6 \%$ para $4,5 \%$, durante a década de 80 . $\mathrm{E}$ os Produtos Minerais não-Metálicos, cuja quota passou de $0,8 \%$ para $1,9 \%$. Todos os outros aumentos foram moderados, apesar do progresso dos Produtos Metálicos» (Lança, 2000: 23).

Por outro lado, a indústria portuguesa, que detinha «uma quota de $75 \%$ do mercado interno, em 1970, e de cerca de $80 \%$, entre 1975 e 1985 , regride para os 59\%, em 1996». Esta evolução é atribuível principalmente a duas indústrias. A Indústria dos Produtos Metálicos passa de 54\%, em 1970, para apenas 34\%, em 1996. Surpreendentemente, as indústrias Têxteis, Vestuário e Couro, que detinham 92\% do mercado doméstico, em 1970, passam para $60 \%$, em 1996, enquanto a sua taxa de cobertura se situa em 1,92 (Lança, 2000: 23-25). A perda de quotas no mercado interno é, no entanto, um fenómeno geral, iniciado ou acentuado após 1985» (Lança, 2000: 23-25). Este é um dos efeitos mais visíveis da integração europeia.

\subsection{Uma competitividade assente nos baixos custos salariais}

Mas se é verdade que o têxtil-calçado é o principal pólo de especialização da indústria portuguesa, essa competitividade continuava, mesmo em 1996, assente nos baixos custos salariais, situação, segundo alguns autores, decorrente da impressionante imobilidade estrutural verificada até ao início da década de 90, nomeadamente no domínio da 
José M. Amado Mendes, António Rafael Amaro e Manuel Ferreira

Rodrigues

mão-de-obra, apesar das medidas adoptadas na década anterior e de os indicadores mais recentes darem sinais evidentes de mudança (Lança, 2000: 27).

De facto, os sectores referidos apresentam uma enorme fragilidade no domínio da qualificação dos recursos humanos, estando mesmo «à cabeça na baixa escolarização, com mais de $90 \%$ dos efectivos e com 6 ou menos anos de escolaridade, e encontram-se entre os sectores pior posicionados quanto à existência de efectivos a um nível de escolarização superior ou secundária». É exactamente nas indústrias têxtil e do couro que se encontra o valor mínimo da taxa de licenciados (Lança, 2000: 23; Godinho e Sousa, 2000: 90). Este quadro reflecte a situação global no nosso país, a reforçar a tese de que os baixos níveis de escolarização favorecem a formação de padrões muito baixos de desenvolvimento (Machado e Costa, 1998: 24). Nessas circunstâncias, não é de estranhar que a remuneração média horária dos trabalhadores destes sectores, especialmente do vestuário e do calçado, se encontre no extremo inferior. «A conclusão a tirar é a de que estamos perante uma competitividade baseada nos baixos custos salariais, com mão-de-obra de muito baixo nível médio de qualificação, reunida em empresas organizacionalmente pouco desenvolvidas, sobretudo no vestuário e no calçado» (Lança, 2000: 29-30). Pelas razões aduzidas como por outras adiante indicadas, os esforços financeiros das empresas com a formação profissional são diminutos, como é exactamente o sector das indústrias Têxteis, do Vestuário e do Couro onde se regista a menor proporção de investimento imaterial (despesa em I\&D) no volume de vendas (Godinho e Sousa, 2000: 88-89).

Tudo isto, apesar do discurso «pedagógico» oficial e da promulgação de algumas medidas políticas adoptadas no sentido de refrear esse fenómeno. Em 1991, o Ministro da Indústria sublinhava a necessidade de mudança, no âmbito do anúncio de um conjunto de apoios à reestruturação do sector: «No quadro da União Económica e Monetária Europeia, a época de competitividade, baseada em baixos salários, acabou. Se nós queremos ser um país com um estatuto europeu, temos de ter salários aproximados aos dos outros países do continente» (Amaral, 1991: 63).

Globalmente, era este o retrato da indústria têxtil em Portugal, até 1995, embora uma análise micro revele, no período em análise, alguns subsectores onde a realidade é algo diferente, como já foi referido anteriormente. Assim, o subsector têxtil é cada vez mais uma indústria de capital intensivo, onde o que conta são os equipamentos, a tecnologia, a 
capacidade de financiamento. No caso do vestuário, a tecnologia ainda não arranjou soluções para utilizar o capital intensivo. Portanto, como refere L. Mira Amaral, a mão-de-obra ainda é fundamental, o que explica, aliás, que em Portugal as dificuldades residam mais no sector vestuário do que no do têxtil (Amaral, 1991: 64).

Por último, devemos acrescentar um elemento não menos significativo para a compreensão das alterações introduzidas: a competitividade destas indústrias assentou, até à criação da Moeda Única, no instrumento cambial, no mecanismo de desvalorização do escudo face às outras moedas.

\subsubsection{A indústria «entalada» entre os baixos preços dos salários e a qualidade dos produtos e a pontualidade das entregas}

O Tratado de Adesão, assinado em 12 de Julho de 1985, depois de oito anos de consultas (a adesão fora pedida em Março de 1977), entrou em vigor em Janeiro de 1986. A partir de Março de 1986, os novos membros comunitários começaram a fasear as tarifas industriais numa base de reciprocidade com os produtos da CEE, até 1 de Janeiro de 1993, data da entrada em vigor do Mercado Único, que visa a eliminação das barreiras não tarifárias, particularmente as barreiras técnicas, administrativas e fiscais, a livre circulação de bens, serviços, capitais e pessoas na Comunidade.

$\mathrm{O}$ alargamento da CEE verificou-se numa altura, em que a indústria e o comércio europeus haviam chegado a um ponto de estagnação. As razões dessa situação eram devidas, segundo John Drew, aos seguintes fenómenos:

- crise económica e desemprego na Europa;

- preocupação com a competitividade internacional da Europa comparada com os Estados Unidos da América e o Japão;

- incerteza sobre a capacidade da Europa, no espaço de poucas décadas, face a uma nova era de comunicações, electrónica e indústrias de serviços;

- a certeza crescente do papel-chave da indústria e da incapacidade dos governos para resolverem os problemas referidos, sem uma cooperação activa dos sectores industriais e comerciais (Drew, 1986: 13). 
Na verdade, a entrada dos novos países era tida como necessária para a criação de mais riqueza e emprego, injectando algum optimismo contra um anunciado «declínio europeu». A propósito, diga-se, de passagem, que esse receio continua agora mais forte do que nunca e isso não deixará de se reflectir na evolução da indústria portuguesa. Segundo M. Mira Godinho, «a década de 90 poderá ter constituído o início de uma fase de divergência económica entre a UE e os EUA, depois da longa convergência real verificada nas décadas posteriores à II Guerra Mundial. A produtividade do trabalho, que era nos países da UE da verificada nos EUA em 1960, atingiu em 1990 uma proporção superior a 80\%. No entanto, desde o início da década de 90 essa produtividade não voltou a subir» (Godinho, 2000: 37-38). Outros autores consideram que esse fenómeno era evidente desde o choque petrolífero de 1973 (Drew, 1986: 15).

No que respeita aos três sectores em apreço, as expectativas portuguesas oscilavam então entre um optimismo moderado e um exagerado pessimismo. Os sectores europeístas mais esclarecidos esperavam que as medidas de reestruturação necessárias à adesão conduzissem a:

- consideráveis aumentos de produtividade através da introdução de inovações técnicas e da automatização dos processos de fabrico;

- diferenciação de produtos; aumento de qualidade;

- transferência de partes da produção para localizações mais favoráveis em custos salariais (Ashoff et al., 1980: XI).

A importância estratégica dessa reestruturação ficava a dever-se, desde logo, ao facto de Portugal ser o país em que a indústria têxtil e de vestuário tinha, nas vésperas da adesão, maior importância macroeconómica, medida na produção, nas exportações e no emprego e, simultaneamente, ser o país com mais baixo nível de desenvolvimento ou de produtividade. Por outro lado, contrariamente a muitos países em desenvolvimento e, sobretudo, aos outros dois países aderentes - a Espanha e a Grécia - Portugal perdera quotas no mercado europeu de têxteis e vestuário na segunda metade da década de 70 (Ashoff et al., 1980: XIII).

Nessa altura, as razões desse fenómeno residiam essencialmente na aposta quase exclusiva da vantagem dos custos salariais que, então, já não era «garante de futuros êxitos consideráveis de exportação» (Ashoff et al., 1980: XIV). Como referiam os autores citados, «na maior parte da indústria portuguesa têxtil e de vestuário predominam estruturas 
tradicionais que são o resultado do modelo económico autárcico-colonial da ditadura praticado durante várias décadas. Consideráveis êxitos de crescimento que, no entanto, só se estendiam a um número restrito de empresas, baseavam-se no passado sobre a utilização dos salários extremamente baixos na produção para o mercado europeu» Ashoff et al., 1980: XIII).

Internamente, o alargamento da CEE ocorre no terminus de um período recessivo de 1982-1984. Em 1983, o défice da balança de transaç̧ões correntes atingira um valor sem precedentes, equivalente a 11,6\% do PIB, enquanto a inflação se situava acima dos 20\% (Mateus, 1998: 117 e S. Fuller et. al., 2000: 21-29). Essa situação conduzira à aceitação do apoio do FMI que impusera um novo programa de estabilização assente num plano global «de contenção monetária e orçamental, acompanhado por políticas realistas e flexíveis ao nível da taxa de juro, taxa de câmbio e preços administrativos» e num conjunto de «esforços destinados a moderar o crescimento dos rendimentos nominais» (Mateus, 1998: 120). A inflação caiu de 29\%, em 1984, para 9,4\%, em 1987 (Fuller et. al., 2000: 26).

De facto, tem então início uma notável fase de expansão, de abertura da economia portuguesa e de estabilidade política, durante a qual se lançaram reformas estruturais profundas, responsáveis pela extraordinária transformação da realidade portuguesa a diversos níveis. Liberalizaram-se e flexibilizaram-se os mercados financeiros, do trabalho e da habitação, o ensino básico passou de seis para nove anos, o investimento público e privado registou forte expansão, especialmente no domínio das infraestruturas, deu-se início à política de privatizações. O gap de convergência em relação à UE reduziu-se de cerca de $20 \%$, entre 1984 e 1995, ritmo sem precedentes na história económica portuguesa (Mateus, 1998: 141). Como refere Abel Mateus, «do ponto de vista dos bens de consumo, esta evolução significou o acesso dos consumidores a uma variedade e qualidade de produtos que representa significativo acréscimo de utilidade. Do ponto de vista do progresso técnico, significou uma substancial transferência de tecnologias, sob a forma de conhecimentos, equipamentos, padrões de funcionamento e técnicas de gestão, que o contacto com os países mais desenvolvidos proporciona», para além de uma maior «sincronia entre o ciclo económico de Portugal e o da UE e a notável subida da produtividade na indústria portuguesa em relação à UE. Entre 1985 e 1991, a produtividade cresceu em Portugal 22 pontos percentuais acima da UE», apesar ${ }^{\mathrm{de}}$ o nosso país ter recebido, «em termos líquidos, em transferências da Comunidade Europeia. Em 1991, Portugal 
José M. Amado Mendes, António Rafael Amaro e Manuel Ferreira

Rodrigues

recebia apenas 155 ECU per capita, contra 655 da Irlanda e 277 da Grécia» (Mateus, 1998: 141 e 150). Em matéria de convergência, nesses dez anos, entre 1986 e 1995, «o gap de rendimento per capita, em PPP, reduziu-se cerca de 13 pontos percentuais, ritmo jamais alcançado apenas numa década, na história económica dos dois últimos séculos» (Mateus, 1998: 154). De 1985 a 1996, a economia portuguesa cresceu à média de 4,2\% (idem: 159). No entanto, as transformações operadas na indústria de um modo geral e nos têxteis, vestuário e calçado, em particular, eram limitadas.

Se, no momento da adesão, Portugal se encontrava «ensanduichado» entre os mais baixos custos dos factores - especialmente de mão-de-obra - dos países que iniciam o processo de industrialização, como a Índia e o Paquistão, e a maior produtividade e qualidade e provavelmente da qualidade de Espanha e da Grécia, sem falar de países como a Inglaterra, a Alemanha e a Itália, que utilizam factores imateriais e dinâmicos de competitividade, já em 1991, o próprio Ministro da Indústria, L. Mira Amaral, reconhecia a persistência desse fenómeno (Amaral, 1991: 64). Podemos dizer que essa situação não mudou substancialmente. Jorge de Vasconcelos e Sá prevê até que «Portugal ficará "entalado" entre os seus concorrentes que obtêm um melhor desempenho em termos de custos e os concorrentes com maior capacidade de adaptação e pontualidade nas entregas» (Sá et al., 1998: 105-107).

Apesar de tudo, nos últimos anos, a situação tem estado a mudar. Alguns responsáveis e dirigentes associativos são peremptórios: «A subcontratação pura e dura está condenada. Portugal já não é mais competitivo para o trabalho a feitio, em que o cliente chega cá com o tecido, os moldes, o design e os acessórios, limitando-se a alugar o minuto de produção», pois, em 1998, o minuto de produção em Portugal andaria pelos $18 \$ 00-20 \$ 00$. Na Tunísia custa $10 \$ 00-11 \$ 00$. E os países de Leste conseguem oferecer preços na ordem dos $7 \$ 00$. Não é neste domínio que podemos competir. Outras vozes vão enunciando os pontos de fuga da mudança em curso: «A nossa competitividade assenta num tripé: qualidade, preço e prazo de entrega [...]. A proximidade geográfica e cultural dos clientes, bem como a credibilidade técnica e de serviço têm sido os nossos grandes trunfos. O futuro reside na manutenção dos prazos de entrega, na flexibilidade e na nossa maneira muito própria de nos relacionarmos com os clientes» ${ }^{9}$.

Como se sabe, contrariamente à teoria tradicional da vantagem comparativa, o «papel do custo dos factores tem perdido importância à medida que, desde a II Guerra Mundial, as indústrias se baseiam em 
conhecimento-intensivo» (Monitor Company, 1994: 58). Mas, na década de 80 e especialmente nos anos 90 , esse fenómeno é já consensual entre os agentes económicos como entre os governos, que concebem a política industrial em moldes diferentes.

Como referem diversos economistas e responsáveis políticos, «a fase do crescimento em quantidade chegou ao fim. As empresas vão agora crescer em qualidade, o que significará que em termos de facturação esta até pode aumentar» (Amaral, 1991: 63). A partir da década de 80 está largamente conquistada a ideia de que a competitividade das empresas é em muito função da sua capacidade de inovação e da sua supremacia tecnológica e organizativa, das suas ligações, da sua cultura. De igual modo está também presente a ideia de que um funcionamento adequado dos mercados é aquele que suscita comportamentos inovadores (Guimarães, 1998: 36).

Assiste-se, desde então a uma inversão de protagonismo entre o Estado e as empresas. Assim, «a dinâmica de inovação e, de um modo mais geral, a criação de uma capacidade competitiva por parte das empresas são consideradas como da responsabilidade destas últimas», enquanto o papel dos governos consistirá na adopção de políticas industriais e tecnológicas de competitividade e de internacionalização que têm «características supletivas e horizontais, concentrando os recursos existentes na criação de infra-estruturas e/ou estruturas de enquadramento atraentes para os planos das empresas à procura de localizações optimizadas numa economia global» (Guimarães, 1998: 38, 118-119, 126-128 e Mateus et al., 1995: 249-298). Estes fenómenos vieram recentrar o papel da empresa e do empresário no processo económico, na senda Coase e Shumpeter.

As dificuldades do caso português decorrem da esmagadora presença de pequenas e muito pequenas empresas, familiares, dotadas de diminutos recursos para a promoção da competitividade no mundo actual, criadas em ambientes histórica e sociologicamente muito específicos. Por isso, muitos defendem «que a política de inovação (...) deve ser essencialmente orientada para as pequenas e médias empresas e os recursos estruturais europeus e orçamentais, que seja possível afectar a este tipo de empresas, venham doravante a ser essencialmente consignados à estimulação de duas lógicas essenciais subjacentes "às actividades de inovação em ambiente de pequena dimensão" - a saber, "a contextualização" e os "processos endógenos de aprendizagem". O que não é fácil, dadas as exigências conceptuais e institucionais inerentes» (Guimarães, 1998: 134). 


\subsubsection{Pequenas empresas familiares e empresários self-made}

No tocante à evolução do tecido empresarial português, especialmente durante a década de 80 , a maior parte dos autores enumera as seguintes características:

- intensa renovação do tecido empresarial. Depois de se ter assistido, nos anos 50 e 60, à verticalização dos processos produtivos e à consolidação de «dinastias empresariais», assistiuse paulatinamente a uma deslocação das fábricas das margens dos cursos de água para a proximidade das vias de comunicação. Nos anos 80, assiste-se a uma desverticalização produtiva e à multiplicação das unidades industriais. Mais de $60 \%$ das empresas têxteis e vestuário do concelho de Guimarães foram criadas depois de 1974. Mas o fenómeno não se circunscreve apenas ao Vale do Ave. A segunda metade dos anos 70, segundo Maria das Dores Guerreiro, parece ter favorecido a constituição de novas empresas, nomeadamente de $\mathrm{PME}^{10}$;

- manutenção do elevado peso das muito pequenas e pequenas empresas (10 a 19 trabalhadores e 20 a 99 trabalhadores, respectivamente), que representam cerca de três quartos do total. Financeiramente, apresentam uma estrutura de capitais mais vulnerável, embora especialmente as muito pequenas apresentem uma maior rendibilidade financeira;

- a esmagadora maioria das empresas é constituída por sociedades por quotas $(85 \%)$, enquanto as sociedades anónimas representam $12 \%$ do total, no estudo de I. Salavisa Lança;

- no tocante à propriedade verifica-se um enorme peso do capital familiar, o que explica o baixo índice de profissionalização da gestão;

- na fileira têxtil-couro predominam as empresas-oficinas, a laborar em regime de subcontratação de facto, mesmo quando não de jure (Lança, 2000: 64-66 e 72-73; Major e Silva, 2000: 108-115 e Silvano, 1997: 25).

Assim, segundo Isabel Salavisa Lança, pode afirmar-se, globalmente, que «a empresa dominante é uma sociedade por quotas de capital familiar, gerida em exclusividade pelos seus proprietários» (Lança, 2000: 77). Trata-se, de resto, de uma característica do tecido empresarial português. «Embora proprietárias, as famílias - diz Maria das Dores Guerreiro - caracterizam-se não tanto pelo usufruto passivo dos 
rendimentos ou pelo investimento de capitais próprios em negócios de terceiros, mas sobretudo por se envolverem directamente na direcção do empreendimento e na actividade da organização que possuem», o que possibilita «importantes zonas de sobreposição entre esfera familiar e esfera empresarial, entre vida doméstica e vida profissional» (Guerreiro, 1996: 247). Desse modo, e ainda segundo esta investigadora, «as habituais distinções, na esteira de Schumpeter, entre capitalista, empresário, e gestor também não apresentam aqui a nitidez de outros contextos económicos e organizacionais. Aquelas figuras tendem a sobrepor-se bastante nas famílias proprietárias e dirigentes de pequenas empresas, sendo muitas vezes preenchidas por equipas empresariais familiares, mais ou menos extensas, constituídas formalmente no quadro organizacional da empresa e informalmente no espaço doméstico e das interacções familiares, responsáveis pela condução dos destinos de grande número destas unidades económicas» (Guerreiro, 1996: 248).

De facto, essa caracterização do tecido empresarial composto pelas pequenas e médias empresas portuguesas não contradiz, no essencial, o retrato de vários outros estudos (Cardoso et al., 1990 e Mateus et al., 1995: 249-298), nomeadamente do Relatório Porter, que considerava deveras singular a situação portuguesa no domínio da estratégia, estrutura e rivalidade empresariais: $96 \%$ das empresas portuguesas, de natureza familiar, empregam menos de 50 trabalhadores, enquanto os gestores portugueses são caracterizados por serem principalmente self-made, orientados para a produção, financeiramente avessos ao risco e hierárquicos no seu estilo de gestão, manifestando um elevado grau de individualismo, o que conduz à falta de planeamento estratégico, de uma gestão por objectivos, de uma definição de negócios e de um posicionamento estratégico (Monitor Company, 1994).

Sobre a importância económica e social das pequenas e médias empresas e a especificidade portuguesa no contexto europeu, os números são claros: ocupam $70 \%$ da população activa. Só as chamadas microempresas, que empregam até 9 trabalhadores, preenchem 95\% do tecido empresarial português, a maior proporção existente no total dos países da Comunidade Europeia (Guerreiro, 1996: 1).

Um conjunto de condicionantes históricas (natureza do desenvolvimento capitalista português, escassez de matérias-primas e de fontes energéticas, difusão de ideias corporativistas, desde o último quarto do século XIX, natureza do processo de formação do Estado Moderno, etc.) poderão explicar as referidas características dos industriais portugueses, a que teremos de acrescentar outras, difundidas e 
José M. Amado Mendes, António Rafael Amaro e Manuel Ferreira Rodrigues

«abençoadas» oficialmente pelo discurso e pelas práticas políticas oficiais, especialmente durante o Estado Novo: a aversão pela concorrência (Mateus et al., 1995: 253-262) e a consequente dependência do Estado. Como dizia L. Valente de Oliveira, em 1995, «a nossa cultura é mais favorável ao "espírito administrativo" do que ao "espírito empreendedor"» (Oliveira, 1995: 180).

Mas a pequena empresa não é em si uma pecha. Onde há que mudar pode ler-se no Relatório Porter, como na maioria dos discursos dos responsáveis pela política industrial do período pós-adesão - é, fundamentalmente, no domínio da organização e na estratégia. Assim, as empresas portuguesas foram aconselhadas, no fim de uma crise, a combinar a eficiência das grandes com a flexibilidade das pequenas, apostando fortemente na qualidade das interligações: «sem as interligações que relacionam as empresas entre si, as pequenas empresas portuguesas não podem fazer grandes investimentos em I\&D ou em distribuição».

Como se vê, em termos globais, a empresa e o empresário portugueses dos três sectores em análise, em abstracto, estão longe dos perfis da empresa e do empresário europeus, traçados nomeadamente pelo Relatório do Comité Pocock sobre a necessidade de formação e educação dos empresários, de que se destaca a exigência de eles procurarem perceber como são tomadas as decisões a nível central e regional, por forma a poderem influenciar os governos e sobre a necessidade de se desenvolver conhecimento dentro das empresas (Drew, 1986: 124).

\subsection{Promissores sinais de mudança}

No entanto, desde o início da década de 90, apesar das dificuldades conjunturais sentidas, entre 1991 e 1994, algo tem estado a mudar no tecido empresarial português, nos sectores em apreço. Destacaremos, pela sua incidência directa nas PME, os efeitos de alguns instrumentos que visam promover a conversão e modernização do tecido empresarial, a excelência em diversos domínios, as interligações, a gestão de informação, o marketing e o design, para além do esforço governamental de cooperação com as organizações empresariais, de reconversão das unidades consideradas inviáveis e especialmente de reforço da capacidade de comercialização das empresas. Como refere L. Mira Amaral, em 1991, «existe uma grande vulnerabilidade nos sectores industriais tradicionais 
portugueses, onde muitas vezes se pensa só na capacidade produtiva e geralmente se descura todo o aspecto da comercialização e controlo dos circuitos de distribuição nos mercados. A oferta portuguesa é extremamente atomizada, enquanto a procura é oligopolizada através de cadeias que dominam facilmente os mercados, levando ao esmagamento dos preços, uma vez que não controlamos os produtos comerciais» (Amaral, 1991: 65).

Além dos instrumentos dedicados, importa sublinhar, também, a importância que teve especialmente para a indústria do Vale do Ave a renovação e construção da rede de estradas, nomeadamente a ligação Porto a Braga por auto-estrada, que desenharam fluxos inter e intraregionais decisivos para o desenvolvimento desta Região, facilitando o crescimento de centros urbanos de menor importância. Note-se que ainda não há muitos anos um camião TIR chegava a gastar um dia, das fábricas ao aeroporto ou ao porto de Leixões (Fiel, 1998: 48). A modernização das comunicações facilitou os contactos com clientes estrangeiros e reforçou o papel do Porto como centro da Região, papel que era seu desde muito cedo, especialmente desde o final do século XVIII, quando as medidas pombalinas the atribuíram o privilégio do selo da alfândega (1774.11.22). Como refere Jorge Fernandes Alves, o Porto tornar-se-ia «uma autêntica plataforma de distribuição do comércio colonial, em que as exportações e importações de produtos têxteis são componentes decisivas: saem grandes quantidades de produtos de linho, incluindo os famosos bordados, e chegam fardos de algodão em rama» (Alves, 1998: 12).

Desse esforço conjunto, nomeadamente as medidas levadas a cabo pelo Instituto de Apoio às Pequenas e Médias Empresas (IAPMEI), destacamos a criação do Gabinete de Apoio à Criação de Empresas, os programas de formação de empresários, os programas de cooperação empresarial, a criação de mecanismos de financiamento com o envolvimento dos sete maiores grupos financeiros portugueses (apesar das tradicionais reservas face às PME), o RETEX, o lançamento do PEDIP, etc. (Almeida, 1993: 11). Também as associações sectoriais, como a ANIVEC (Associação Nacional dos Industriais de Vestuário e Confecção), a APIM (Associação Portuguesa dos Industriais de Malha), a APT (Associação Portuguesa de Têxteis e Vestuário) e a APIV (Associação Portuguesa dos Industriais de Vestuário), que representam os interesses das empresas que as constituem, têm promovido acções e programas específicos de apoio às estratégias empresariais com vista ao desenvolvimento no quadro de um mercado global, e, por conseguinte, mais competitivo e exigente (Duarte, 2000: 26). 
O prémio PME Prestígio, atribuído pelo IAPMEI e pelo Banco Nacional Ultramarino (BNU) para premiar empresas que no ano anterior tivessem tido melhores desempenhos, permitiu às premiadas o acesso mais fácil à carteira de instrumentos financeiros do IAPMEI. Em 1993, foram escolhidas 66 empresas de têxteis e vestuário - 53 da Região Norte - e 15 de calçado e curtumes, representando $17 \%$ de um universo de 400 contempladas com o referido estatuto (Pequena e Média Empresa, 1993: 54-66). As empresas têxteis seleccionadas tinham uma média de 193 trabalhadores e apresentavam um volume médio de vendas por empresa, no ano de 1992, de $1075000000 \$ 00$ (cerca de 5300000 Euros). Já as 15 empresas de calçado contempladas empregavam em média 171 trabalhadores e venderam, em média, um valor aproximado ao dos têxteis e vestuário, isto é, $1042125000 \$ 00$ (cerca de 5190000 Euros) (ibidem). Sublinhamos, contudo, tratar-se de uma amostra muito variada de PME; uma das empresas de têxteis e vestuário seleccionadas empregava 11 trabalhadores, tinha um capital social de $30000000 \$ 00$ e um volume de vendas de $614050000 \$ 00$; da mesma relação faz parte um outra que empregava 658 trabalhadores, tinha um capital social de $600000000 \$ 00$ e vendeu no mesmo ano $1816414000 \$ 00$, e ainda uma outra que empregava 393 trabalhadores, possuía um capital social de $3100000 \$ 00$ e apresentou um volume de vendas da ordem dos $2879412000 \$ 00$, isto é, perto de três vezes a média das empresas premiadas.

Mas nesse vasto universo de milhares de empresas, como resultado dos desafios colocados pela integração europeia e como resposta a um variado conjunto de fenómenos sociais relacionados, internamente, com o aumento do consumo, com os novos estilos de vida, o aumento da escolaridade e o incremento da urbanização, um número crescente de empresas tem vindo a modernizar-se.

Numa avaliação muito sumária do impacte da integração europeia na estruturação industrial, especialmente nos têxteis e no vestuário, em 1998, Abel Mateus assinalava: «transferiram-se recursos da tecelagem e de outras manufacturas de fios e tecidos para o vestuário e lanifícios. Estas indústrias, tal como as de calçado, têm registado significativa melhoria a nível de design e marketing, nomeadamente através da ligação com cadeias internacionais e de "marcas"» (Mateus, 1998: 164).

De facto, diversos são os sinais de mudança, apesar do horizonte de crise em que a indústria têxtil se move, aquilo a que J. Vasconcelos e Sá chamou «Sucesso no meio da Crise» (Sá et al., 1998). Sinais tímidos? Na verdade, cada vez mais o design conquista os industriais portugueses e como resultado dessa mudança de atitude surgiram várias escolas de 
design industrial, nomeadamente design têxtil, com incidência particular no Norte de Portugal.

É evidente que «a indústria tenta, de alguma forma, apostar na qualidade, integrando designers nas suas equipas; os nomes de estilistas e criadores multiplicam-se; os acontecimentos ligados à moda proliferam e reúnem pequenas multidões; as revistas e os manequins são conhecidos» (Leonardo, 2000: 9-10). Isso tem tido contrapartidas. Ultimamente, «as empresas têxteis têm vindo a redesenhar as suas estratégias de gestão no sentido da modernização dos equipamentos e do aumento da qualidade do produto, bem como da rapidez e da flexibilidade da resposta» (Duarte, 2000: 46). Os próprios criadores realçam o facto de que, «é muito importante que o acto da criação se faça com uma componente industrial forte, isto é, na concepção da própria colecção. O evoluir da moda tem necessariamente de passar pela industrialização, de contrário nunca deixará de ser um projecto de passerelle» (Duarte, 2000: 46 e Leonardo, 2000: 10).

Nos anos 90, o ICEP - Instituto do Comércio Externo Português desenvolveu alguns instrumentos de apoio à internacionalização dos criadores de moda (Duarte, 2000: 26). Entre os eventos surgidos com essa intenção, destaca-se o «Portugal Fashion», criado no Porto, em 1995, pela ANJE - Associação de Jovens Empresários, espevitando a «ModaLisboa», criada no início da década de 90 . Surgem diversos nomes de «criadores exemplares» que dividem a sua actividade entre o ensino do design têxtil - algumas escolas foram fundadas por eles - e a colaboração com várias empresas, criando marcas próprias, assinando diversas colecções (Ana Salazar, Nuno Gama, José António Tenente, Maria Gambina, Luís Buchinho, Miguel Vieira, Helena Matos, Osvaldo Martins, etc.) (Féria, 2000: 28-35).

Entre as várias empresas têxteis e de vestuário modernas, algumas merecem destaque pela excelência atingida em vários domínios, permitindo que o Made in Portugal compita nos mercados europeus mais sofisticados (Serrão, 2000: 40). Começa a ser regra que «quando se trata de fabricar roupa interior, a encomenda pode ir para Hong Kong. Mas se se trata de valores da ordem das 700 libras por um fato é melhor mandálo a quem o fabrica melhor» (Fiel, 1998: 46). Alguns responsáveis pelo sector, como Henry Tillo, presidente da Associação Portuguesa de Têxtil e Vestuário, afirmam mesmo que «a imagem da nossa qualidade é boa. Está ligeiramente abaixo da dos italianos, mas claramente acima da dos gregos e da dos países de Leste» (Fiel, 1998: 46). 
Desse modo, o Aeroporto de Pedra Rubras, no Porto, é escala obrigatória dos compradores das mais caras e prestigiadas marcas de roupa. Pólos Ralph Lauren? Fabricados em Guimarães, pela Guima (Grupo Somelos). Camisas Gianfranco Ferré? Confeccionadas no Porto, pela Têxtil Nortenha. Fatos Hugo Boss? Produzidos em Rio Tinto, pela Silva \& Sistelo. Sweats marca O’Neill? Feitas em Mogege, pela Filobranca. Blusões Levi's Strauss? Fabricados na Maia, pela Eurêxtil. Parkas Paul \& Shark? Vieram da Delcon, em Ribeirão. Blasers Yves de Saint-Laurent? Feitos em Famalicão, pela Ricon. Camisolas Alain Manoukian? Made by Malhas Minho, em Braga. A lista podia continuar provando que Made in Portugal «está na moda; a indústria têxtil portuguesa teve artes de escapar ao apocalipse anunciado» (Fiel, 1998: 46).

Uma questão que esta enumeração levanta é a da criação de marcas portuguesas. Referem alguns empresários que «uma marca própria custa milhões de contos. Recentemente, só para lançar um novo tipo de tecido, a Levi's investiu 200 milhões de dólares em marketing. É muito difícil e caro. Exige uma loja-âncora em cada grande mercado». Outros opinam que «não há empresa portuguesa com dinheiro suficiente para lançar uma marca própria de exportação», pois isso "significa um investimento muito grande. Exigia uma mudança de mentalidade e que Portugal fosse conhecido como um país de moda, como a Itália, a França e os EUA. E, infelizmente não é (...). Uma página no Der Spiegel custa 8000 contos. Dez são 80 000. Quem tem dinheiro para o marketing que o lançamento de uma marca acarreta?» (Fiel, 1998: 48).

Atente-se na indicação e sumária caracterização de algumas das empresas mais competitivas deste sector ${ }^{11}$ :

- Jotex - «Os grandes investimentos efectuados têm passado por uma preocupação de inovação tecnológica, mas também por uma aposta na criação e design através da colaboração do designer Luís Buchinho, bem como pela comercialização directa das suas marcas através da abertura de lojas a nível nacional e internacional. A Jotex só trabalha com marcas próprias que cria e distribui em função da estratégia adoptada para cada segmento de mercado». Pela comercialização das suas marcas podia igualmente ser referenciada a Sociedade de Confecções Dielmar, SA.

- Fábrica Têxtil Riopele, SA - é a empresa que tem maior volume de exportações dentro da indústria têxtil e do vestuário. «A Riopele tornou-se exemplar, uma vez que apostou na conquista 
dos mercados internacionais como forma de ganho de competitividade a um nível global».

- Têxtil Manuel Gonçalves - fundada em 1937 por Manuel Gonçalves, é a empresa com maior volume de negócios na indústria têxtil e do vestuário. Procedeu recentemente a uma cisão em quatro unidades com vista à «definição de estratégias centradas em cada um dos core-business, permitindo uma maior flexibilidade para responder às alterações do mercado, quer interno, quer externo».

- Endutex Revestimentos Têxteis - salienta-se no grupo das empresas com suporte de uma forte estrutura financeira e com maior rendibilidade «de capitais próprios, com um valor máximo próximo dos $59 \%$. Igualmente a rendibilidade das vendas mostra o maior valor do sector têxtil e vestuário, com $17 \%$ ».

- Lameirinho, Riopele e Silva \& Sistelo - destacam-se não pela produção com marcas próprias mas por incluírem, entre os seus clientes nomes como os da Marie Claire, Laura Ashley e Marks \& Spencer, Nikki Bosh, entre muitas outras.

- Arco-Têxteis. Empresa Industrial de Santo Tirso, SA - fundada em 1923, sendo um empresa familiar, gerida e dirigida pelos descendentes do fundador, é um exemplo do que de melhor se faz em Portugal, com um volume de negócios que atingiu $6406008000 \$ 00$ (cerca de 31900000 Euros). Trata-se de «uma unidade vertical que comercializa fios e tecidos, sendo a venda de tecidos colocada em cerca de $60 \%$ nos mercados europeus e os restantes $40 \%$ no mercado português e no resto do mundo».

- Grupo Maconde Confecções - fundada em 1969, em Vila do Conde, «na área da confecção, a Maconde é um dos cinco maiores produtores de vestuário exterior de homem de toda a Europa e o maior confeccionador e exportador deste sector em Portugal, sendo que a Europa, a América do Norte e o Japão são os seus mercados destinatários da sua produção [...]. Para a distribuição, o grupo Maconde opera como grossista e retalhista, quer na distribuição de vestuário de moda, quer nos têxteis-lar», tendo aberto recentemente uma unidade em Casablanca, Marrocos, que emprega 158 pessoas. Da sua carteira de encomendas, especialmente de casacos, constam marcas sonantes, como a Gap, a Banana Republic ou a Calvim Klein.

- Estamparia Adalberto Pinto da Silva - fundada em 1973, em Rebordões, Santo Tirso, esta empresa é especializada em 
tinturaria, estampagem e acabamentos, produzindo edredões, toalhas de mesa, capas, lençóis, tecidos de decoração e panos de cozinha.

\section{CONCLUSÃO}

Depois de três décadas de relativo fechamento ao exterior, os anos Sessenta marcam o início de um ciclo de profundas e rápidas transformações. Até 1973, vive-se a época de ouro do crescimento económico português. Depois de uma década conturbada, caracterizada pelo impacte do fim do modelo de desenvolvimento do segundo pósguerra e pelos efeitos da Revolução de 1974 (descolonização, instabilidade política e ascensão de novas elites políticas e económicas), Portugal inicia o processo de integração europeia, durante o qual as empresas são chamadas a desempenhar papel de primacial importância económica e social. Tem então início uma fase de expansão do investimento público e privado, de abertura da economia e de estabilidade política; liberalizaram-se e flexibilizaram-se os mercados financeiros, do trabalho e da habitação, deu-se início às privatizações, assistiu-se a uma substancial transferência de tecnologias, sob a forma de conhecimentos, equipamentos, padrões de funcionamento e técnicas de gestão, construiuse e renovou-se a rede viária. Reduziu-se o gap de convergência em relação à União Europeia.

À semelhança do que se passou no resto do País, como expressão de um fenómeno de longa duração, assistiu-se, no período em apreço, ao reforço da desindustrialização do interior, em favor do crescimento urbano e suburbano e da concentração industrial num pequeno número de concelhos do litoral, que responsáveis cada vez mais pelo grosso da riqueza da Região Norte.

A despeito de nela se encontrarem algumas das nossas maiores empresas, a Região do Norte de Portugal é composta, maioritariamente, por pequenas e médias unidades. Outro aspecto característico é o da grande diversidade sub-regional em diversos domínios. O interior e alguns concelhos do litoral contrastam em diversos aspectos com a concentração industrial mono-sectorial do Vale do Ave, uma das subregiões mais dinâmicas da Região.

No período estudado, a indústria da Região Norte sofreu diversas transformações dignas de nota, embora, como foi sublinhado, tenhamos 
de falar de mais mudanças e de conversões estruturais do que de modernização. Por isso, é justo dizer que a adesão de Portugal à CEE foi benéfica, mas não foi uma varinha mágica. A Região Norte regista, como característica do seu tecido económico, uma excessiva representação de actividades industriais de fraco valor acrescentado e uma subrepresentação do Sector de Serviços, muito embora este sector tenha registado um crescimento significativo nos últimos anos.

No domínio da gestão, o facto mais saliente, apesar da escassez de estudos sobre o tema, assistiu-se à emergência dos gestores profissionais (licenciados em engenharia, gestão, economia, etc.), em detrimento dos patrões de indústria. Embora o processo já se tivesse iniciado décadas atrás, é bem possível que a adesão de Portugal à CEE tenha contribuído, também na Região Norte do país, para a substituição ainda em curso do capitalismo empresarial, de tipo familiar, pelo capitalismo de gestão. De qualquer modo, predominam as sociedades por quotas de capital familiar, geridas em exclusividade pelos seus proprietários, o que constitui, como foi provado, uma característica do tecido empresarial português.

No domínio da mão-de-obra, importa sublinhar dois aspectos referidos em diversos estudos: 1. a Região Norte de Portugal possui uma das populações mais jovens da União Europeia; 2. os seus níveis de escolaridade são baixos (três quartos dos trabalhadores por conta de outrem possuem menos do que o $9 .^{\circ}$ ano de escolaridade), apesar da relativa abundância de recursos humanos com habilitação superior, o que decorre da própria estrutura empresarial dominante. Desse modo, o ritmo de substituição de trabalhadores com baixo nível de qualificação tem sido bastante lento, o que se reflecte necessariamente no adiamento da modernização do tecido económico. Foi o sector terciário que absorveu mão-de-obra mais qualificada. De resto, esses fenómenos não são muito diferentes do que se passa no resto do país, mas que contrasta com o que se passou nos nossos parceiros da «Coesão».

Os têxteis, o vestuário e o calçado, porque se encontram fortemente representados na Região Norte, porque constituem o núcleo duro da competitividade industrial portuguesa e até o principal pólo de especialização industrial portuguesa, foram escolhidos para uma avaliação global dos efeitos da integração europeia.

Um dos aspectos mais evidentes é o de que a Comunidade Europeia passou a ser o mercado natural da maioria das empresas industriais; por outro lado, diminuiu fortemente a quota de mercado interno: passam de 92\%, em 1970, para 60\%, em 1960. 
Como refere a maioria dos autores, a competitividade destes sectores continuava, em 1996, a assentar nos baixos custos salariais, apesar do discurso «pedagógico» e das medidas políticas de sentido contrário tomadas nas duas últimas décadas. No entanto, uma análise micro revela uma realidade em mudança em alguns subsectores, nomeadamente nos de capital intensivo, onde a tecnologia, o equipamento e o financiamento são decisivos, como no têxtil.

Assim, apesar dos efeitos da crescente sincronia entre o ciclo económico de Portugal e o da União Europeia, do aumento da produtividade e da preferência pelos mercados europeus o nosso país continua «ensanduichado» entre os países de mais baixos custos dos factores e os de maior produtividade, qualidade e pontualidade. Como referem diversos autores, essa situação tem estado a mudar. Existe um consenso generalizado de que a fase do crescimento em quantidade chegou ao fim, que as empresas vão agora crescer em qualidade, situação que é favorecida pelas mudanças registadas nas últimas décadas no domínio da relação Estado/Empresa.

De qualquer modo, ficou provado existirem promissores sinais de modernização. Milhares de empresas, como resultado dos desafios colocados pela integração europeia e pela globalização e como resposta a um variado conjunto de fenómenos sociais relacionados, internamente, com o aumento do consumo, com os novos estilos de vida, o aumento da escolaridade e o incremento da urbanização, um número crescente de empresas tem vindo a modernizar-se. No tocante aos três sectores seleccionados, as melhorias mais evidentes registam-se nos domínios do design e do marketing.

\section{NOTAS}

* O presente estudo foi elaborado no âmbito do Programa ALFA ("Priferias". 5. 0012. 8), o qual, além dos autores, integrou igualmente investigadores dos seguintes países: Espanha, Brasil, México e Uruguai. Teve como coordenador geral o Prof. Mario Cerutti, da Universidad Autónoma de Nuevo León (Monterrey, Máxico).

${ }^{1}$ Referindo-se ao desempenho de Portugal no quadro da União Europeia, escreve Daniel Bessa: «É conhecida a excelência deste desempenho no chamado plano nominal: Portugal conseguiu, em poucos anos e contrariando a generalidade das expectativas, baixar a taxa de inflação para níveis próximos da média comunitária, estabilizar a taxa de câmbio em relação às moedas mais fortes da União e diminuir o défice público para níveis inferiores a $3 \%$ do PIB. (...) o PIB por habitante a preços 
correntes e em paridade de poderes de compra, expresso em percentagem da média comunitária, teria crescido, em Portugal, de 55, 9\%, em 1986, para 71\% em 1997. Um resultado francamente positivo, só excedido pelo da Irlanda (de 62,2\% para 98,2\%) e largamente superior ao dos outros dois países «da Coesão»: a Espanha passou de $70,2 \%$ para $77,8 \%$ e a Grécia de 60,4\% para 68,6\%» (Bessa, 1999: 135).

${ }^{2} \mathrm{O}$ mesmo Daniel Bessa, justificando a sua afirmação, apresentou os seguintes dados: a Região de Lisboa e Vale do Tejo, com 33,3\% da população, não contribui com mais do que 34,9 para o produto industrial, contribuindo com $47,7 \%$ para o produto nacional no sector dos serviços (Bessa, 1999: 137).

${ }^{3}$ Diz a este propósito Daniel Bessa: «numa perspectiva mais global, faz-se sentir na Região Norte o mesmo tipo de assimetria que caracteriza todo o Continente: apenas o Grande Porto apresenta um valor do Índice Composto de Desenvolvimento superior à média nacional. Todo o resto da Região está abaixo da média nacional: para além do Tâmega, do Alto Trás-os-Montes e do Douro.

${ }^{4}$ Em 1991, 22,1\% da população tinha menos de 15 anos, entre 15-24, 18,0\%, entre $25-39,22,3 \%$, entre $40-54,16,4 \%$, entre $55-64,9,7$ e com mais de $65,11,4 \%$.

${ }^{5}$ Bessa, 1999: 136. Estes dados de Daniel Bessa confirmam os elaborados por nós, apenas os utilizámos pelo facto de o autor fazer uma comparação com valores de países da UE e por não querermos desvirtuar os resultados apurados por este economista.

${ }^{6}$ O Vale do Ave compreende uma área total de $1469 \mathrm{~km}^{2}$ e uma população de 579297 habitantes, o que corresponde a uma densidade de $394 \mathrm{hab} / \mathrm{km}^{2}$, valor superior à densidade média da Região Norte, que é de 163 hab $/ \mathrm{km}^{2}$ (Silvano, 1997: 22 e Silva, 1987).

${ }^{7}$ Em 1999, a produção exportada rondaria já os $85 \%$, iniciando-se a expansão para outros mercados: Leste Europeu, Estados Unidos da América e Mercosul (Duarte, 2000: 46).

${ }^{8}$ Dá-se então uma forte expansão das exportações em têxteis, vestuário, calçado e pasta de papel (Mateus, 1998: 165).

${ }^{9}$ Manuel Serrão, Henry Tillo e Lemos Costa, em Jorge Fiel (1998: 48-52).

10 Em 1970, existiam 571 sociedades. Às cinco maiores, a Têxtil Manuel Gonçalves, a Fábrica Têxtil Riopele, a Sociedade Têxtil Albano Coelho de Lima (Coelima), as Indústrias Têxteis Somelos e a Empresa Fabril do Norte, correspondiam 11,4\% das receitas e 9,8\% do pessoal (Martins, 1973: 105-106). No seu estudo, M. das Dores Guerreiro contabilizou 66\% de unidades empresariais criadas nos anos 70-90 (Guerreiro, 1996: 25).

${ }^{11}$ As empresas referidas bem como os dados indicados foram recolhidos em Serrão, 2000: 40-45 e Fiel, 1998: 46-52. 


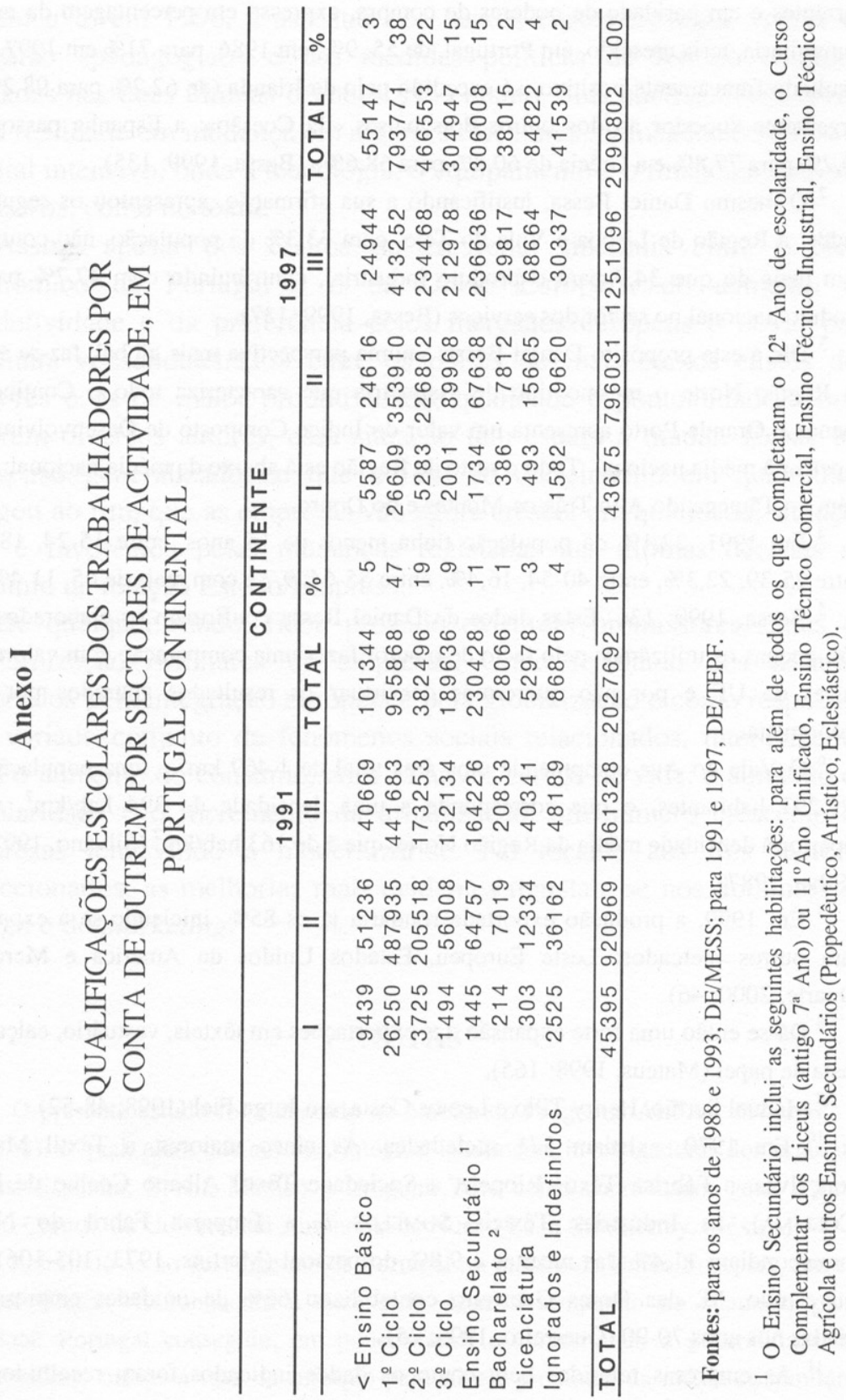




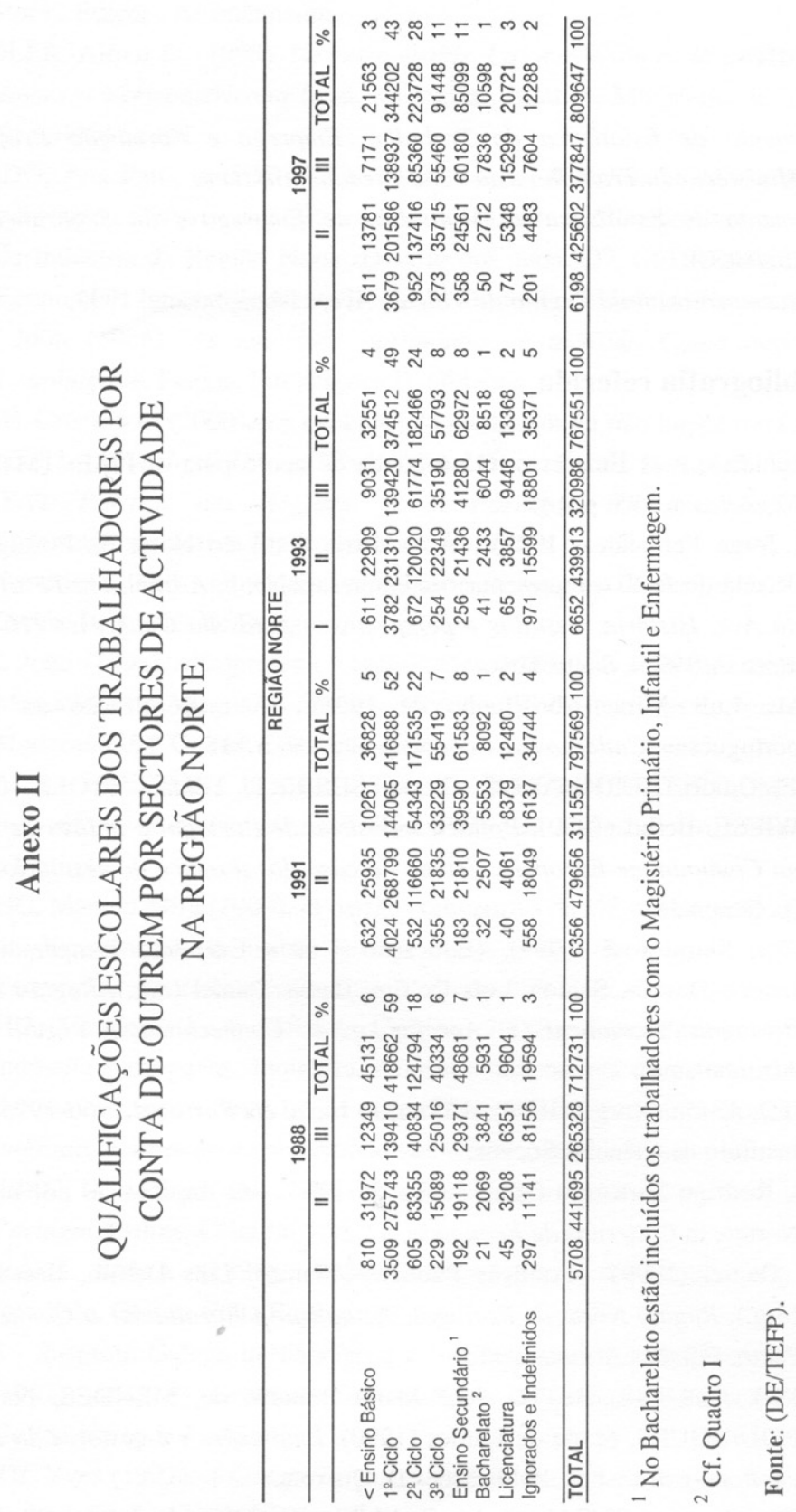




\section{FONTES E BIBLIOGRAFIA}

\subsection{Fontes}

Departamento de Estatística do Trabalho, Emprego e Formação Profissional, Ministério do Trabalho e da Solidariedade (DE/TEPF)

Departamento de Estatística do Ministério do Emprego e da Segurança Social (DE/MESS).

Estrutura empresarial da Região do Vale do Ave, Lisboa, IAPMEI, 1993.

Eurostat, Portrais des Régions: 3.

\subsection{Bibliografia referida}

«A Comunidade e as Empresas: O programa de apoio para as PME» (Maio 1988) Negócios, n. ${ }^{\circ} 85$, p. 14.

ALVES, Jorge Fernandes (1998), «A indústria têxtil do Norte de Portugal até à década de 1920 - representações empresariais», in A Indústria Têxtil no Vale do Ave. História, desafios e perspectivas. Actas do Congresso (16 e 17 de Maio de 1996), Santo Tirso.

AMARAL, Luís Mira (Abril/Junho de 1991), «A modernização da indústria portuguesa», Cadernos de Economia, ano IV, n. ${ }^{\circ} 15$.

ASHOFF, Guido, BURKHARDT, Gisela, SEIBERT, Tilman, STOLZ, Günter, WIESE, Bernd (1980), Política industrial de Portugal e indústrias em crise na Comunidade Europeia. Estudo do caso dos têxteis e do vestuário. Berlim, (policopiado).

AZEVEDO, Maria José (1999), «Educação - ou o Exercício Temperado de um Direito-Dever», Santos, Luís Delfim, Bessa, Daniel (Org.), Região Norte de Portugal: Actualizar e Aprofundar o Conhecimento, Porto, Edições Afrontamento.

BARRETO, António (org.) (1996), A situação social em Portugal,1960-1995, Lisboa, Instituto de Ciências Sociais.

BEIRES, Rodrigo Sarmento (Abril-Junho de 1994), «O impacto do pdr na Região Norte», in Cadernos de Economia, . $^{\circ} 27$.

BESSA, Daniel (1999), «Políticas Públicas», Santos, Luís Delfim, Bessa, Daniel (org.), Região Norte de Portugal: Actualizar e Aprofundar o Conhecimento, Porto, Edições Afrontamento.

CARDOSO, José Luís, BRITO, José Maria Brandão de, MENDES, Fernando e RODRIGUES, Maria de Lurdes (1990), Empresários e gestores da indústria em Portugal, Lisboa, Publicações D. Quixote, 
CASTRO, Alberto, GONZÁLEZ, Maria do Pilar (1999), «Mercado de Trabalho da Região Norte: Estabilidade e Evolução», Santos, Luís Delfim, Bessa, Daniel (Org.), Região Norte de Portugal: Actualizar e Aprofundar o Conhecimento, Porto, Edições Afrontamento.

CHANDLER, Alfred D. (1998), La mano visible. La revolución en la dirección de la empresa norteamericana (trad. do inglês), Madrid, Ministerio de Trabajo y Seguridad Social.

DELGADO, Ana Paula e GODINHO (1994), Maria, A Indústria da região Norte: caracterização estrutural, Relatório final do estudo "Perspectivas de evolução da Indústria da Região Norte. Desafio dos anos 90", CEDRES - Centro de Economia e Desenvolvimento Regional, Porto, Faculdade de Economia.

DREW, John (1986), As empresas portuguesas e a CEE. Como negociar na Comunidade, Lisboa, Publicações D. Quixote.

DUARTE, Cristina L. (2000), «A evolução da moda tem ou não impacto na indústria têxtil?», Anuário de Design Têxtil, n. ${ }^{\circ}$ 1, Lisboa, Centro Português de Design.

EUROSTAT, Portrait des Regions, t. 3: Portugal, Espagne, Itali, Grèce, Eurostat/Commission des Commités Européenes, s. d.

FÉRIA, Lourdes (2000), «Criadores exemplares», in Anuário de design têxtil, Lisboa, Centro Português de Design.

FREIRE, João (1998), «Empresas e organizações. Mudanças e modernização», José Manuel Leite Viegas e António Firmino da Costa (orgs.), Portugal, que Modernidade? Oeiras, Celta Editora.

FUller, S., PRESTON, J., MODESTO, L., LEITE-MONTEIRO, M. (2000), Indicadores de actividade económica. Portugal, Lisboa, Porto, Lisboa, Livros e Leituras.

GODINHO, Manuel Mira (2000), «Posição competitiva da UE nos anos 90. A ameaça da divergência», in Isabel Salvisa Lança (org.), A indústria portuguesa. Especialização, internacionalização e competitividade. Oeiras: Celta Editora.

GODINHO, Manuel Mira e SOUSA, Cristina (2000), «Panorama tecnológico da indústria portuguesa. Inquérito identifica indicadores de esforço», in Isabel Salvisa Lança (org.), A indústria portuguesa. Especialização, internacionalização e competitividade. Oeiras: Celta Editora.

GUERREIRO, Maria das Dores (1996), Famílias na actividade empresarial: PME em Portugal, Oeiras, Celta Editora.

GUIMARÃES, Rui A. (1998), Política industrial e tecnológica e sistemas de inovação, Oeiras, Celta Editora.

IGE-INE - Instituto Galego de Estatística e Instituto Nacional de Estatística (19941997), Atlas de Empresas Galicia-Norte de Portugal/Atlas de Empresas Galiza-Norte de Portugal. 
LACOSTE, Yves (1997), A Geografia serve antes de mais para fazer a guerra (trad. do francês), Lisboa, Iniciativas Editoriais.

LANÇA, Isabel Salavisa (2000), A indústria portuguesa. Especialização, internacionalização e competitividade. Oeiras: Celta Editora.

LEONARDO, Ana Cristina (2000), «Resenha histórica do que foi e é hoje o design têxtil de autor em Portugal», in Anuário de design têxtil, Lisboa, Centro Português de Design.

MACHADO, Fernando Luís e COSTA, António Firmino da, «Processos de uma modernidade inacabada. Mudanças estruturais e mobilidade social», in José Manuel Leite Viegas e António Firmino da Costa (orgs.), Portugal, que Modernidade, Oeiras, Celta Editora.

MACHADO, João de Sousa (1998), «Política comercial da União Europeia. Algumas notas relativas ao enquadramento futuro do Comércio Mundial de Têxteis $\mathrm{e}$ Vestuário e suas repercussões em Portugal», in A Indústria Têxtil no Vale do Ave. História, desafios e perspectivas. Actas do Congresso (16 e 17 de Maio de 1996), Santo Tirso.

MAGALHÃES, Maria Madalena Allegro de (1988), "A indústria do Porto na primeira metade do século XIX», Revista da Faculdade de Letras (Porto) Geografia, I série, vol. IV, p. 111-154.

MARQUES, Ludgero (1989), «O Norte como factor determinante do desenvolvimento económico de Portugal», A Indústria do Norte, n. $^{\circ} 28$.

MARTINS, Maria Belmira (1973), Sociedades e Grupos em Portugal, Lisboa, Editorial Estampa.

MATEUS, Abel (1998), Economia Portuguesa desde 1910, Lisboa, Editorial Verbo.

MATEUS, Abel (1998), Economia portuguesa. Crescimento no contexto internacional (1910-1998), Lisboa - São Paulo, Editorial Verbo.

MATEUS, Augusto et al. (1995), Portugal XXI - Cenários de desenvolvimento, Lisboa, Bertrand.

MENDES, José Amado (1993), «A indústria da seda em Portugal nos fins do Antigo Regime: decadência e estímulo», Arqueologia Industrial, 2. ${ }^{\mathrm{a}}$ série, vol. I, n. ${ }^{\mathrm{o}} 1$, p. 55-62.

MENDES, José Amado (1994), A área económica de Coimbra. Estrutura e desenvolvimento industrial, 1867-1927), Coimbra, Comissão de Coordenação da Região Centro.

MENDES, José Amado (1996), «Portugal agrícola ou industrial? Contornos de uma polémica e suas repercussões no desenvolvimento (sécs. XIX-XX)», Revista de História das Ideias, 18: História. Memória. Nação, p. 187-230.

MONITOR COMPANY (sob dir. Michael Porter) (1994), Construir as Vantagens Competitivas de Portugal, $2^{\mathrm{a}}$ ed., Lisboa, ed. Forum para a Competitividade. 
MONIZ, António Brandão (1989), «Mudanças tecnológicas e organizações em Portugal: análise das duas últimas décadas», Organizações e Trabalho, n. ${ }^{\circ} 1$, Novembro, p. 7-23.

MONIZ, António Brandão (Novembro de1998), «Modernização da indústria portuguesa: análise de um inquérito sociológico», Economia e Sociedade, n. ${ }^{\circ} 1$.

Negócios (Maio 1988), «Comunidades europeias: A comunidade e as empresas. o programa de apoio para as PMEs, Negócios, n. ${ }^{\circ} 85$, p. 14-21.

OLIVEIRA, Luís Valente de (1995), «Iniciativa e mentalidade empresarial. Estratégias empresariais», in Loco de Notas. Sobre o muito que devemos fazer para preparar o futuro, Porto, Edições Asa.

Pequena e Média Empresa: Ramalho de Almeida, Presidente do IAPMEI, em entrevista à Pequena e Média Empresa, n. ${ }^{\circ}$ especial, Dezembro de 1993.

Portugal. Quadro comunitário de apoio. 1994-1999. Objectivo $n .{ }^{\circ}$ 1: Desenvolvimento e ajustamento estrutural das regiões menos desenvolvidas, Comissão Europeia, s. d.

Reconversão do tecido industrial, com relevo para o têxtil, na Bacia do Ave: Efeitos na mão-de-obra. Estudo realizado no âmbito do PEDIP (1993), Lisboa, Ministério da Indústria e Energia-Direcção Geral da Indústria, (mimeog.).

Região do Minho-Lima. Estrutura Empresarial (1993), col. «Estruturas Empresariais», IAPMEI.

REI, Constantino Mendes e Lisboa, João Veríssimo (1993), «A dimensão e desempenho das empresas industriais portuguesas. Análise de 350 empresas industriais», Notas Económicas, n. ${ }^{\circ}$ 2, p. 54-63.

RIBEIRO, Orlando (1986), Portugal, o Mediterrâneo e o Atlântico, 3. ${ }^{a}$ ed., Lisboa, Sá da Costa.

SÁ, Jorge Vasconcelos e et al. (1998), Sucesso no meio da crise: o caso dos Têxteis e Confecções. Lisboa: Instituto de Emprego e Formação Profissional (col. «Estudos», n. ${ }^{\circ} 22$ ).

SÁ, Jorge Vasconcelos e, AMARAL, Maria do Céu, MORAIS, Fernando Óscar Branco de Sousa (1998), Sucesso no meio da crise. O caso dos têxteis e confecções, Lisboa, Instituto do Emprego e Formação Profissional (col. «Estudos», n. $\left.{ }^{\circ} 22\right)$.

SANTOS, Luís Delfim, BESSA, Daniel (org.) (1999), Região Norte de Portugal: Actualizar e Aprofundar o Conhecimento, Porto, Edições Afrontamento.

SERRÃO, Joel (1953), «Porto, 1830», Temas Oitocentistas - I: Para a História de Portugal no século XIX. Ensaios, reed., Lisboa, Livros Horizonte, 1980, p. 8691 (anteriormente publicado, de forma mais desenvolvida, sob o título «A indústria portuense em 1830», Bulletin d'Études Historiques, n. ${ }^{\circ}$ 1, Lisboa, p. 7-22). 
José M. Amado Mendes, António Rafael Amaro e Manuel Ferreira Rodrigues

SERRÃO, Manuel (2000), «Empresas têxteis exemplares», in Anuário de design têxtil, Lisboa, Centro Português de Design.

SILVA, Mário Rui (1987), O desenvolvimento industrial do Vale do Ave. Relatório intermédio de sintese, Porto (exemplar policopiado).

SILVANO, Filomena (1997), Territórios da Identidade, Oeiras, Celta Editora, 1997. 